\title{
Kansas Law Review Criminal Procedural Survey - 2018 Supplement
}

\section{TABLE OF CONTENTS}

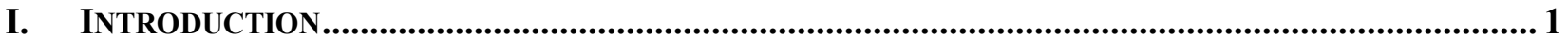

II. SEARCHES AND THE FOURTH AMENDMENT ................................................................................. 1

United States v. Zuniga-Leija,

No. 16-CR-20109-JAR, 2017 WL 3215678 (D. Kan. July 28, 2017) ...................................... 1

State v. Howard,

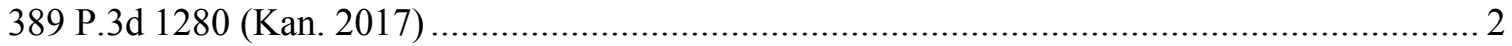

State v. Bannon,

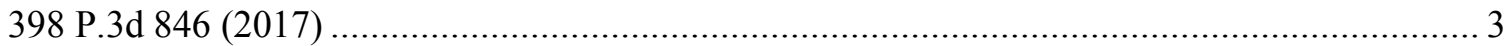

State v. Carr,

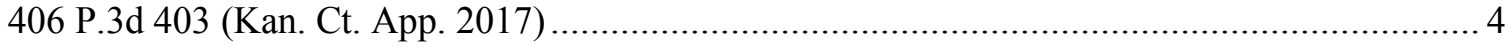

United States v. Nelson,

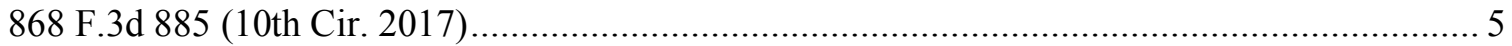

State v. Ryce,

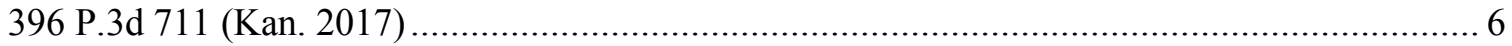

State v. Baker,

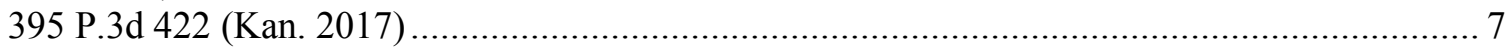

State v. Wilson,

No. 115,554, 2017 WL 3444509 (Kan. Ct. App. 2017)........................................................... 8

State v. Robinson,

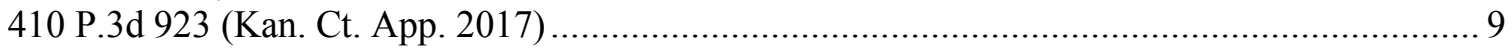

City of Dodge City v. Webb,

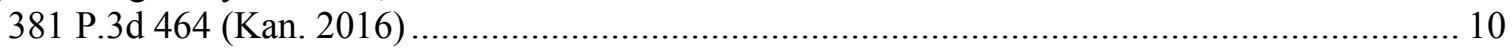

State v. Nece,

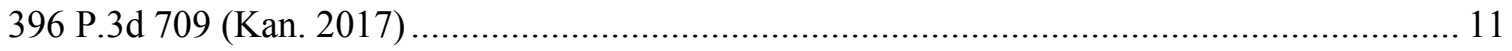

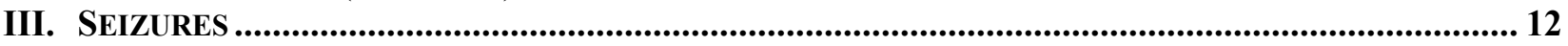

United States v. Thompson,

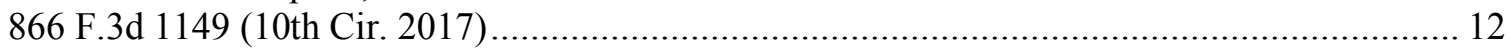

State v. Maier,

No. 115,248, 2017 WL 4216264 (Kan. Ct. App. Sept. 22, 2017) ........................................... 12

State v. Lewis,

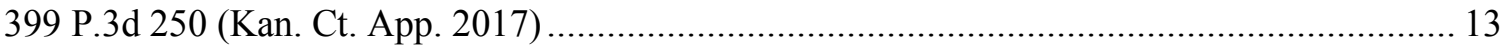

State v. Glover,

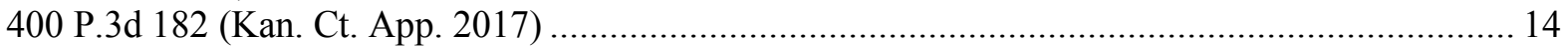

State v. Dannebohm,

No. 116,981, 2017 WL 3447883 (Kan. Ct. App. Aug. 11, 2017) .......................................... 14

State v. Mattox,

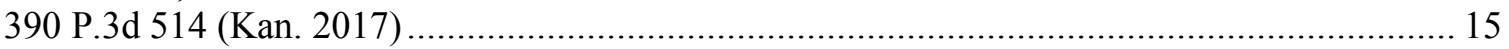

State v. Brown,

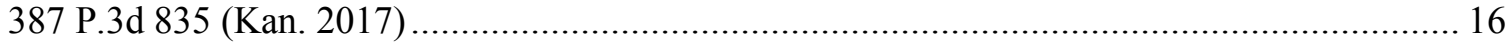

United States v. Yepa,

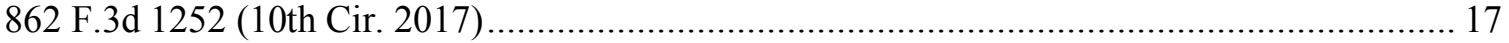

State v. Guein,

388 P. 3d 194 (Kan. 2017) 


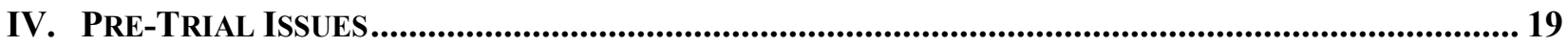

State v. Mosby,

No. 115,598, 2017 WL 2610765 (Kan. Ct. App. 2017)......................................................... 19

Brown v. State,

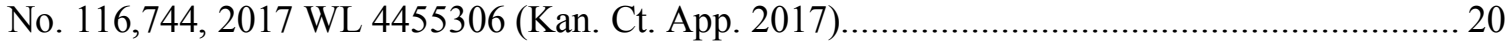

State v. Robinson,

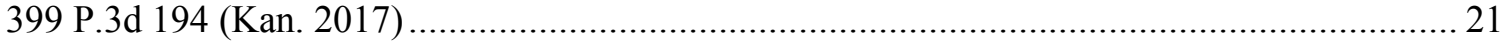

State v. McDaniel,

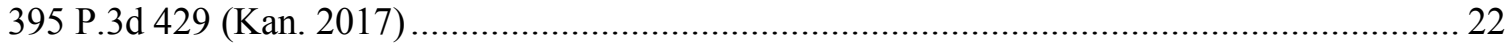

Wahl v. State,

No. 114,888, 2017 WL 3668917 (Kan. Ct. App. Aug. 25, 2017) ........................................... 23

State v. Johnson,

No. 110,837, 2017 WL 4558235 (Kan. Ct. App. October 13, 2017)...................................... 24

United States v. Trinh,

No. 17-MJ-90007-GEB, 2017 WL 3675102 (D. Kan. Aug. 25, 2017) …............................... 25

State v. Beck,

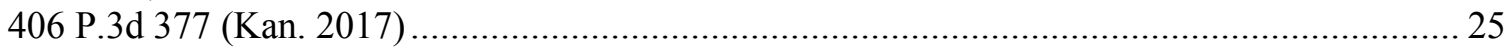

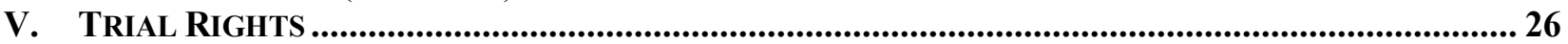

United States v. Williston,

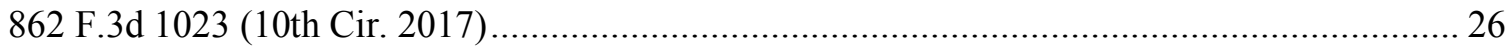

Weaver v. Massachusetts,

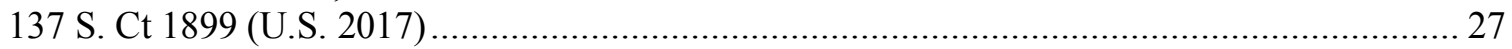

Pena-Rodriguez v. Colorado,

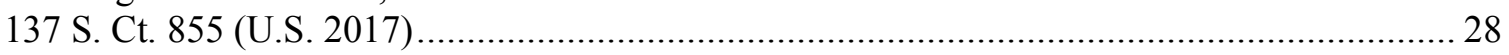

State v. Chapman,

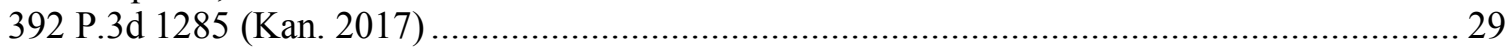

Lee v. United States,

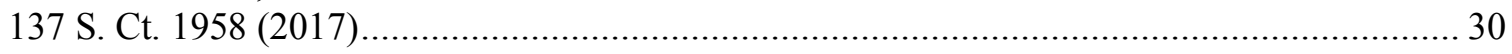

United States v. Williamson,

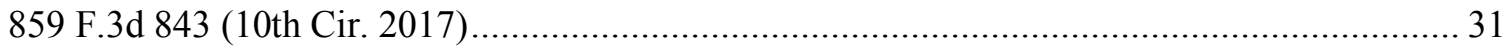

Khalil-Alsalaami v. State,

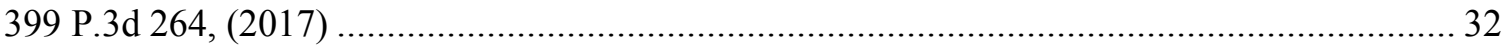

State v. Dartez,

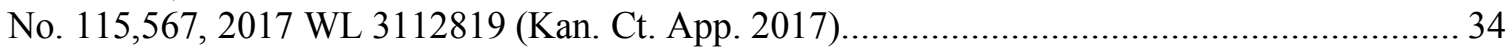

State v. Perez,

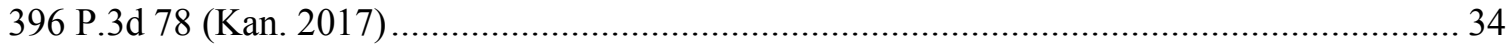

State v. Williams,

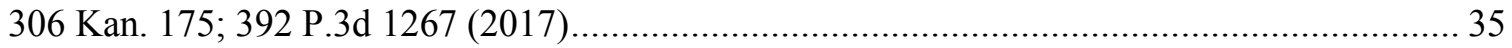

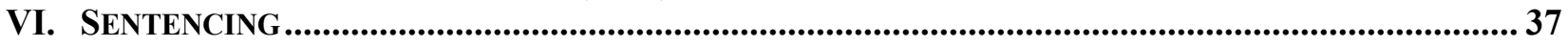

KAN. STAT. ANN. § 21-6620 (West 2017);

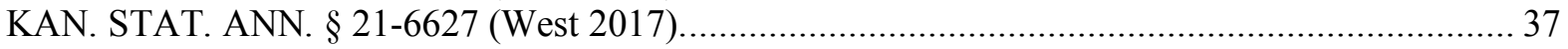

State v. Allen,

407 P.3d 661 (Kan. Ct. App. 2017) 


\section{Kansas Law Review Criminal Procedural Survey - 2017 Supplement}

\section{INTRODUCTION}

The 2018 Supplement to the Kansas Law Review Criminal Procedure Survey (the "Supplement") was compiled by staff members and the Note and Comment Editors of the Kansas Law Review. The 2018 Supplement is intended to provide a snapshot of the changes in criminal procedure law in 2017. This Supplement should be read in conjunction with the 2016 Criminal Procedure Survey, which provides a more detailed review of each area of the law, and the 2017 Supplement. ${ }^{1}$ The 2018 Supplement highlights changes in Kansas criminal procedure law using cases from the Kansas Supreme Court and the Kansas Court of Appeals, along with relevant decisions from the Tenth Circuit Court of Appeals and the United States Supreme Court. This Supplement provides full citations to both state and regional case reporters when applicable. Substantial changes in Kansas statutes are also summarized. Our goal is that the Supplement will serve as a resource to inform practitioners and judges on the development of Kansas criminal procedure law and its current status.

\section{SEARCHES AND THE FOURTH AMENDMENT}

\section{United States v. Zuniga-Leija, No. 16-CR-20109-JAR,} 2017 WL 3215678 (D. Kan. July 28, 2017)

Full Case Citation: United States v. Zuniga-Leija, No. 16-CR-20109-JAR, 2017 WL 3215678 (D. Kan. July 28, 2017).

2016 CPS Section: II.C.1. - Searches and the Fourth Amendment / Exceptions to the Search Warrant Requirement / Consent

\section{Summary:}

The Kansas District Court distinguished United States v. Zuniga-Leija ${ }^{2}$ from the Tenth Circuit decision in United States $v$. Jones, ${ }^{3}$ and provides a detailed analysis for determining what constitutes non-verbal consent to a search. ${ }^{4}$ In Jones, the Tenth Circuit held that an adult defendant — following a police search request — walking to the back door of his house without objecting to police following him counted as non-verbal consent to search the residence. ${ }^{5}$

\footnotetext{
1 U. Kan. L. Rev., Kansas Law Review Criminal Procedure Survey 2016, 64 U. KAN. L. REV. (2016), https:/law.ku.edu/sites/law.drupal.ku.edu/files/docs/law review/v64/2016\%20Crim\%20Pro\%20Survey.pdf; U. Kan. L. Rev., Kansas Law Review Criminal Procedure Survey Supplement 2017, 65 U. KAN. L. REV. (2017), https:/law.ku.edu/sites/law.drupal.ku.edu/files/docs/law review/v65/Kansas\%20Law\%20Review\%20Criminal\%20 Procedural $\% 20$ Survey $\% 20 \% \mathrm{C} 2 \%$ AD $\% 202017 \% 20$ Supplement.pdf.

2 No. 16-CR-20109-JAR, 2017 WL 3215678, at *6 (D. Kan. July 28, 2017).

3701 F.3d 1300 (10th Cir. 2012).

4 Zuniga-Leija, 2017 WL 3215678, at *6.

5 Id. (citing 701 F.3d 1300 (10th Cir. 2012)).
} 
In Zuniga-Leija, the court held there were several factual differences that necessitated a different outcome. ${ }^{6}$ Here, evidence was unclear as to how (or even if) the officers requested to search the home and whether the officers were given permission to enter the home when a 17year-old girl turned away from to door to get her ailing mother. ${ }^{7}$ The district court held that there were too many ambiguities in the facts for the officers' actions to survive the objective reasonable officer standard for determining if consent had been given. ${ }^{8}$ In dicta, the court raised other concerns about the girl and her mother's abilities to give consent to a search. ${ }^{9}$

State v. Howard, 389 P.3d 1280 (Kan. 2017)

Full Case Citation: State v. Howard, 305 Kan. 984, 389 P.3d 1280 (2017).

2016 Sections: II.C.3. - Searches and the Fourth Amendment / Exceptions to the Search Warrant Requirement / Automobiles and Vehicles

\section{Summary:}

Defendant Howard appealed the denial of his motion to suppress the fruits of a search on the grounds that a reclined seat, a plastic baggie with a corner ripped out, and the police officer's experience did not constitute probable cause. ${ }^{10}$ A police officer pulled Howard over for entering a gas station to avoid a traffic light. ${ }^{11}$ Once the vehicles were stopped, the officer noticed that, in the time since he first saw the car, the passenger had reclined her seat. ${ }^{12}$ After taking the defendant's identification, the officer learned that there was a warrant out for his arrest. ${ }^{13}$ The officer had the defendant step out of the car, "scanned" the car for a weapon, and found "a plastic baggie with a ripped out corner." 14 The officer then arrested defendant and placed him in the back of his patrol car. ${ }^{15}$ Next, the officer took the passenger's identification, learned she had a warrant out for her arrest, and had her step out of the car. ${ }^{16}$ The officer required her to remain on a curb 6 to 8 feet away. ${ }^{17}$ He then moved her seat and found a firearm. ${ }^{18}$

At issue on appeal was whether the officer had probable cause to search the vehicle. ${ }^{19}$ The state argued that the officer had probable cause to believe there was contraband or evidence of a crime in the car because of the reclined seat, the clear plastic baggie, and the officer's

\footnotetext{
${ }^{6} I d$.

7 Id.

8 Id.

${ }^{9} I d$. at 7-9.

${ }^{10}$ State v. Howard, 305 Kan. 984, 987, 389 P.3d 1280,1284 (2017).

11 Id. at 986,389 P.3d at 1283.

$12 I d$.

${ }_{13} \mathrm{Id}$

${ }^{14} \mathrm{Id}$.

15 Id.

16 Id.

${ }_{17} \mathrm{Id}$.

${ }_{18}^{18}$ Id.

${ }^{19}$ Id. at 989,389 P.3d at 1285.
} 
knowledge that "twisted off corners of clear plastic baggies" are used to package drugs. ${ }^{20}$ The Kansas Supreme Court found all of these facts persuasive. ${ }^{21}$ First, the court "conclude[d] that it was fair for the officer in this case to infer from the passenger's action of reclining her seat that she was trying to hide something from his view." 22 Second, the court held that the baggie and the officer's knowledge of the use of baggies "helped to establish probable cause." 23 Therefore, the court held that the officer had sufficient facts to establish probable cause and affirmed the denial of defendant's motion to suppress. ${ }^{24}$

State v. Bannon, 398 P.3d 846 (2017)

Full Case Citation: State v. Bannon, 306 Kan. 886, 398 P.3d 846 (2017).

2016 CPS Section: II.C.4.a - Searches and the Fourth Amendment / Exceptions to the Search Warrant Requirement / Exceptions to the Search Warrant / Terry Stops

\section{Summary:}

Defendant Bannon appealed his conviction for the criminal carrying of a firearm in an apartment on the Wichita State University campus. ${ }^{25}$ Bannon argued the district court erred when it failed to suppress the evidence of Bannon carrying a weapon on campus. ${ }^{26}$ The State claimed the search of Bannon's person was lawful under the Terry stop doctrine and K.S.A. 222402, which codified the requirements of a Terry stop. ${ }^{27}$ The Kansas Supreme Court held that regardless of the wording related to officer safety contained in the statute, "the ultimate constitutionality of such a seizure is still measured against the requirements of Terry and the Fourth Amendment." 28 Additionally, the court emphasized that the focus of Terry's second prong remains on "whether the person stopped is armed and presently dangerous." 29

Courts across the country are split on whether "a reasonable suspicion that the person is armed and presently dangerous" is a subjective or objective requirement. ${ }^{30}$ The Kansas Supreme Court adopted the Utah Supreme Court's hybrid approach. ${ }^{31}$ An officer's subjective belief or fear of a suspect being "armed and presently dangerous" is only "one factor in the totality of circumstances examined in an objective analysis of the totality of the circumstances." 32 A police

\footnotetext{
$20 I d$. at 990,389 P.3d at 1286.

21 Id. at $991-94,389$ P.3d at 1286-88.

22 Id. at 991,389 P.3d at 1286.

${ }_{23} I d$. at $993-94,389$ P.3d at $1287-88$.

24 Id. at 994, 389 P.3d at 1288.

${ }^{25}$ State v. Bannon, 306 Kan. 886, 886, 398 P.3d 846, 847 (2017).

${ }^{26} \mathrm{Id}$. at 886,398 P.3d at 847 .

${ }^{27}$ Id. at 892,398 P.3d at $848,851$.

${ }^{28} I d$. at $892-93,398$ P.3d at 851.

${ }^{29} I d$. at 893,398 P.3d at 851.

${ }^{30} \mathrm{Id}$. at 894,398 P.3d at 852 .

${ }^{31}$ Id. at 896, 398 P.3d at 853; see State v. Warren, 2003 UT 36, 78 P.3d 590 (Utah 2003).

32 Bannon, 306 Kan. at 896, 398 P.3d at 853.
} 
officer's subjective belief is insufficient by itself, but courts cannot "completely disregard" the officer's belief. ${ }^{33}$ The Kansas Supreme Court remanded the case because the Court of Appeals failed to correctly apply the Terry test. ${ }^{34}$

\section{State v. Carr, 406 P.3d 403 (Kan. Ct. App. 2017)}

Full Case Citation: State v. Carr, 54 Kan. App. 2d 780, 406 P.3d 403 (2017).

2016 CPS Section: II.C.4.a - Searches and the Fourth Amendment / Exceptions to the Search Warrant Requirement / Other Circumstances in Which Limited Searches are Allowed Without a Warrant or Probable Cause / Terry Stops

\section{Summary:}

Defendant appealed his convictions for marijuana possession and aggravated battery, claiming error in the denial of his motion to suppress fruits of an illegal Terry stop. ${ }^{35}$ Defendant was a passenger in a vehicle at the time of the stop. ${ }^{36}$ The officers testified that they stopped the vehicle because they believed it might be associated with the defendant, who was a suspect in a drive-by shooting they were investigating. ${ }^{37}$ The officers' believed that the vehicle was associated with defendant because one of Defendant's relatives owned the same type of car and the officers had seen the car at the defendant's house. ${ }^{38}$ There was no traffic violation to support the stop. ${ }^{39}$

The "central question" for the court on appeal was "whether a wanted person's 'association' with a car alone gives an officer reasonable suspicion to stop that car without other facts or information that suggest the wanted person is in the car on that particular day." Because the officers stopped the vehicle solely because the defendant's relative owned the same type of vehicle and the officers had seen the vehicle at the defendant's house, the court determined that the officers acted on a hunch, rather than reasonable suspicion. ${ }^{41}$ They did not have specific, articulable facts to support reasonable suspicion that Defendant was in the vehicle and therefore the stop was illegal. ${ }^{42}$ Therefore the court erred in denying Defendant's motion to suppress. ${ }^{43}$

\footnotetext{
${ }^{33}$ Warren, 78 P.3d at 596.

${ }^{34} I d$. at 989,398 P.3d at 854.

35 State v. Carr, 54 Kan. App. 2d 780, 782, 406 P.3d 403, 407 (2017)

${ }^{37} I d$. at 409, 54 Kan. App. 2d at 787.

${ }^{38} I d$. .

39 Id.

${ }^{40} I d$. at 410, 54 Kan. App. 2 d at 788.

${ }^{41}$ Id. at 412, 54 Kan. App. 2d at 791-92.

${ }^{42} I d$. at 412, 54 Kan. App. 2d at 792.

${ }^{43} I d$. at 414, 54 Kan. App. 2d at 795.
} 
Full Case Citations: United States v. Nelson, 868 F.3d 885 (10th Cir. 2017).

2016 CPS Section: II.C.4.c - Searches and the Fourth Amendment / Exceptions to the Search Warrant Requirement / Other Circumstances in Which Limited Searches are Allowed Without a Warrant or Probable Cause / Protective Sweeps of Premises

\section{Summary:}

Nelson challenged the district court's denial of his motion to suppress the guns police found when performing a protective sweep his house following Nelson's arrest. ${ }^{44}$ The police arrested Nelson at a residence with four levels. ${ }^{45}$ The police entered on the third level and escorted Nelson's girlfriend to the second level, before seeing Nelson on the first level. ${ }^{46}$ The officers called Nelson to the second floor for arrest. ${ }^{47}$ After arresting Nelson, one officer searched the first level where Nelson was hiding, eventually finding illegal weapons. ${ }^{48}$ Nelson argued the search of the house violated the Fourth Amendment. ${ }^{49}$ The United States argued the search was covered under the protective-sweep doctrine..$^{50}$

The Tenth Circuit held the protective-sweep doctrine requires a reasonable inference that someone else was in the house. ${ }^{51}$ The government cannot rely on the fact that the police had "no way of knowing if anyone else was in the residence." 52 The court held if police possessed no knowledge about the "potential presence of a third person," the government failed to satisfy the protective-sweep doctrine's requirements. ${ }^{53}$ The Tenth Circuit provided examples based on its precedent that might lead to the inference of the presence of another person: specific information another person lived in the home, watching another person enter the house, and the arrestee telling the officers that other people were in the house. ${ }^{54}$ Additionally, police must learn this information before the protective sweep occurs. ${ }^{55}$ The Tenth Circuit remanded the case to the district court to determine whether the police's knowledge was enough to justify the sweep of the first floor. ${ }^{56}$

44 United States v. Nelson, 868 F.3d 885, 887 (10th Cir. 2017).

45 Id. at 888 .

46 Id.

47 Id.

48 Id.

49 Id.

$50 \mathrm{Id}$.

51 Id. at 889.

${ }_{52} \mathrm{Id}$.

${ }_{53} \mathrm{Id}$.

54 Id. at 890; see e.g., United States v. Denson, 775 F.3d 1214, 1219-20 (10th Cir. 2014); United States v.Hauk, 412 F.3d 1179, 1192 (10th Cir. 2005); United States v. Cavely, 318 F.3d 987, 994 (10th Cir. 2003).

55 Id. at 890 .

56 Id. 
Full Case Citation: $\quad$ State v. Ryce, 306 Kan. 682, 396 P.3d 711 (2017).

\section{CPS Sections:}

- II.C.4. - Searches and the Fourth Amendment / Exceptions to the Search Warrant Requirement / Other Circumstances in Which Limited Searches are Allowed Without a Warrant or Probable Cause / Intoxication

- II.G.3. - Searches and the Fourth Amendment / Technology and Searches / Chemical Drug Tests

\section{Summary:}

Ryce challenged the constitutionality of K.S.A. 2016 Supp. 8-1025 after he withdrew his consent to a blood alcohol content breath test. ${ }^{57}$ K.S.A 2016 Supp 8-1025 made it a crime to refuse to submit to a BAC test after giving consent, regardless of whether the consent was explicit or implied. ${ }^{58}$ The Kansas Supreme Court held the statute unconstitutional but agreed to stay its decision until the U.S. Supreme Court decided a similar case before it. ${ }^{59}$ In Ryce I, the Kansas Supreme Court interpreted K.S.A. 2016 Supp. 8-1025 to "penalize[] drivers who refuse to submit to a test that they have impliedly consented to . ..."60 The Kansas Supreme Court concluded both breath and blood tests constituted a search and are per se unreasonable unless they fall within a recognized exception to the warrant requirement. ${ }^{61}$ The Kansas Supreme Court held that consent was the only constitutional basis to uphold breath and blood alcohol searches. ${ }^{62}$ Additionally, the State cannot compel consent by threatening a criminal offense. In Birchfield, the U.S. Supreme Court held that warrantless breath tests were valid under the searches incident to lawful arrest, but blood tests were not. ${ }^{63}$

The Kansas Supreme Court upheld its original determination in Ryce I. ${ }^{64}$ However, the court modified its holding to reflect Birchfield's determination that breath tests could be justified under the search incident to lawful arrest exception. ${ }^{65}$ However, the search incident to lawful arrest exception does not always apply when "an officer demands submission to a blood alcohol content test." 66 Kansas statutes only allow an officer request a driver submit to a test; the officer cannot direct a test unless the driver consents or is unable to consent. ${ }^{67}$ The court held K.S.A.

57 State v. Ryce, 306 Kan. 682, 682, 396 P.3d 711, 711 (2017) (Ryce II).

58 Id., 396 P.3d at $711-712$

59 See State v. Ryce 303 Kan. 899, 368 P.3d 342 (2016) (Ryce I); Birchfield v. North Dakota, 579 U.S. _, 136 S. Ct. 2160 (2016).

${ }^{60}$ Ryce I, 303 Kan. at 907,368 P.3d at 350.

${ }^{61} I d$. at $909-914,368$ P.3d at 350-353.

62 Ryce II, 306 Kan. at 686, 396 P.3d at 713.

${ }^{63}$ Birchfield, 136 S. Ct. at 2184.

${ }^{64}$ Ryce II, 306 Kan. at 691, 396 P.3d at 717.

${ }^{65} I d$. at 693,396 P.3d at 717.

${ }^{66} I d$. at 693,396 P.3d at 718.

${ }^{67} I d$. at 695,396 P.3d at 719 . 
Supp. 2016 8-1025 unconstitutional because, while the state can punish failure to cooperate "with a warrant search or a search conducted pursuant to a warrant exception," it cannot criminalize the withdrawal of implied consent to the test. ${ }^{68}$

\section{State v. Baker, 395 P.3d 422 (Kan. 2017)}

Full Case Citation: $\quad$ State v. Baker, 306 Kan. 585, 395 P.3d 422 (2017).

\section{CPS Sections:}

- II.C.4.e - Searches and the Fourth Amendment / Exceptions to the Search Warrant Requirement / Other Circumstances in Which Limited Searches are Allowed Without a Warrant or Probable Cause / Inventory Search After Arrest

\section{Summary:}

Defendant Baker appealed the denial of his motion to suppress evidence discovered after the police completed an inventory search of his backpack after his arrest. ${ }^{69}$ In Kansas, a warrantless search is per se unreasonable unless it falls into an previously recognized exception. ${ }^{70}$ "One 'well-defined' exception to the warrant requirement is the inventory search, which 'is not an independent legal concept but rather an incidental administrative step following arrest and preceding incarceration." 71 Inventory searches do not rely on probable cause, and a lack of a warrant is immaterial to a search's reasonableness. ${ }^{72}$ For an inventory search to be valid, law enforcement must have lawful custody of the property being inventoried. ${ }^{73}$ Baker argued that the police lacked lawful custody of his backpack because they failed to ask Baker want he wanted to do with it. ${ }^{74}$

The Kansas ${ }^{75}$ Supreme Court disagreed and held its precedents did not allow an arrested person to arrange for the removal of his possessions to avoid their placement in law enforcement's inventory. Impounding an arrested person's possessions must be reasonable under the totality of the circumstances. ${ }^{76}$ The Kansas Supreme Court held the seizure of Baker's backpack reasonable under the circumstances because the arrest occurred at a retail store. ${ }^{77}$ The U.S. Supreme Court previously held that inventory searches did not satisfy the Fourth Amendment's requirements when law enforcement had "no policy whatever with respect to the opening of closed containers encountered during an inventory search."78 The Kansas Supreme

68 Id. at 698-699, 396 P.3d at 720.

69 State v. Baker, 306 Kan. 585, 585, 395 P.3d 422, 424 (2017).

70 Id. at 590, 395 P.3d at 427 (quoting State v. Ramirez, 278 Kan. 402, 404-05, 200 P.3d 94 (2004)).

71 Id. (quoting Illinois v. Lafayette, 462 US 640, 643-44 (1983)).

72 Id.

73 Id. at 591,395 P.3d at 427.

74 Id. at 591, 395 P.3d at 428.

75 Id. at 592, 395 P.3d at 428.

${ }^{76} \mathrm{Id}$.

77 Id.

78 Florida v. Wells, 485 U.S. 1, 4 (1990). 
Court applied the Wells rule to the police's search of Baker's backpack. ${ }^{79}$ Under the Wells rule, law enforcement must have "standardized criteria or an established routine" to regulate opening containers found during an inventory search. ${ }^{80}$ The Kansas Supreme Court wrote that the policy could be opening all containers, no containers, or only those that officers cannot determine their content. ${ }^{81}$ The policy is not required to be written, but one must exist. ${ }^{82}$ The State has the burden to produce some evidence of a policy to satisfy the Fourth Amendment. ${ }^{83}$ The decision reversed the Kansas Court of Appeals' finding that the search was constitutional and remanded the case. ${ }^{84}$

State v. Wilson, No. 115,554, 2017 WL 3444509 (Kan. Ct. App. 2017)

Full Case Citation: State v. Wilson, No. 115,554, 2017 WL 3444509, at*1 (Kan. Ct. App. August 11, 2017).

\section{CPS Sections:}

- II.C.4.e - Searches and the Fourth Amendment / Exceptions to the Search Warrant Requirement / Other Circumstances in Which Limited Searches are Allowed Without a Warrant or Probable Cause / Inventory Search After Arrest

\section{Summary:}

Defendant Wilson appealed a district court's denial of his motion to suppress evidence found during an inventory search of his SUV. ${ }^{85}$ Officer Gaines, who arrested Wilson, decided to impound and tow Wilson's vehicle after arresting Wilson for driving with a suspended license. ${ }^{86}$ At the time of her arrest, Wilson had parked her SUV in a manner which protruded into the entryway of a business parking lot. ${ }^{87}$ Because no one could come move the vehicle, Gaines asked Wilson for the name of her preferred towing company and proceeded to impound and tow the SUV. ${ }^{88}$ Before the tow arrived, however, Gaines conducted an inventory search of the SUV and found cocaine and drug paraphernalia. ${ }^{89}$ Both before and at her trial, Wilson challenged Gaines's decision to impound her vehicle. ${ }^{90}$ Wilson argued that because Gaines's decision to impound was

\footnotetext{
79 Baker, 306 Kan. at 593, 395 P.3d at 429.

80 Id.

81 Id.

$82 I d$.

83 Id.

$84 \mathrm{Id}$.

85 State v. Wilson, No. 115,554, 2017 WL 3444509, at*1 (Kan. Ct. App. August 11, 2017).

86 Id.

${ }^{87} \mathrm{Id}$.

${ }^{88} \mathrm{Id}$.

$89 I d$. at $* 2$.

90 Id.
} 
unreasonable, the subsequent inventory search and seizure was unlawful. ${ }^{91}$ The District Court denied Wilson's motion to suppress. ${ }^{92}$

The Kansas Court of Appeals affirmed the district court's denial of Wilson's motion to suppress the evidence seized from her SUV. ${ }^{93}$ To comport with the Fourth Amendment, the court stated that Gaines's decision to impound must have been "reasonable under the totality of the circumstances." 94 One circumstance the court considered was the fact that no statute or ordinance required Gaines to impound Wilson's SUV. ${ }^{95}$ But that circumstance alone was not dispositive. ${ }^{96}$ The court also considered the hazard posed by the placement of Wilson's car in the entrance to a business parking lot and found that this hazard weighed in favor of impoundment. ${ }^{97}$ Additionally, the court stated that Gaines's inquiry as to Wilson's preferred handling of the SUV "weigh[ed] strongly in favor of a constitutionally reasonable impoundment" because "[t]he inquiry itself points toward an effort to act reasonably under the circumstances." 98 Finally, the court considered whether Gaines's impoundment was subterfuge to search the vehicle, but found the fact that Gaines inquired about Wilson's preferred handling cut against the possibility of subterfuge. ${ }^{99}$ Because the totality of the circumstances suggested that Gaines' decision to impound was reasonable, the court held the search was constitutionally reasonable. ${ }^{100}$

State v. Robinson, 410 P.3d 923 (Kan. Ct. App. 2017)

Full Case Citations: State v. Robinson, 55 Kan. App. 2d 209, 410 P.3d 923 (2017)

2016 CPS Section: II.G.3. - Searches and the Fourth Amendment / Technology and Searches / Chemical Drug Tests

\section{Summary:}

Defendant was charged with refusal to submit to field sobriety testing in violation of K.S.A. 2016 Supp. 8-1012, refusal to submit to testing in violation of K.S.A. 2016 Supp. 8-1025, and driving under the influence. ${ }^{101}$ Under K.S.A. 2016 Supp. 8-1012, any person who operates a vehicle in Kansas is deemed to have given consent to submit to a preliminary breath test

91 Id. .

$92 \mathrm{Id}$.

93 Id. at $* 4$.

94 Id. at *3 (citing State v. Shelton, 278 Kan. 287, 293, 93 P.3d 1200 (Kan. 2004)).

95 Id. (noting that neither the police department's impoundment policy nor a statute mandated impoundment of Wilson's vehicle).

96 Id.

97 Id. at*3 (citing Shelton and State v. Branstetter, 199 P.3d 1272, 40 Kan. App. 2d 1167, 1171(Kan. Ct. App.

2009) for the proposition that an "unattended motor vehicle parked illegally or in a manner that could obstruct traffic present [s] a circumstance weighing in favor of impoundment. A motor vehicle can be considered unattended if the driver has been arrested an no one else is present to remove or lawfully park it.")

98 Id.

99 Id. at $* 4$.

$100 \mathrm{Id}$.

101 State v. Robinson, 55 Kan.App.2d 209, 209, 410 P.3d 923, 923 (2017). 
("PBT"). ${ }^{102}$ Refusal to submit is a traffic infraction. ${ }^{103}$ The defendant moved to dismiss that charge, asserting that K.S.A. 2016 Supp. 8-1012 was facially unconstitutional. ${ }^{104}$

The court held that a similar statute, K.S.A. 2016 Supp. 8-1025, was unconstitutional in Ryce I and Ryce II. ${ }^{105}$ K.S.A. 2016 Supp. 8-1025 "imposes criminal penalties upon a motorist for refusing to submit to any method of blood-alcohol testing." "106 The court held that this was facially unconstitutional because it "criminalizes a defendant's right to withdraw his or her consent to a warrantless search and it is not narrowly tailored to serve a compelling state interest."107

The court in Robinson held that criminalizing the refusal to submit to a PBT in violation of K.S.A. 2016 Supp. 8-1012 is unconstitutional because it criminalizes the right to withdraw consent from a warrantless search - the same reason the court used in Ryce I and Ryce II. ${ }^{108}$ The court compared the unconstitutional statute 8-1025 with statute 8-1012, and determined them to be substantially similar. ${ }^{109}$ Additionally, the court held that K.S.A. 2016 Supp. 8-1012 was not narrowly tailored to serve a compelling state interest. ${ }^{110}$ Ultimately, the court held that K.S.A. 2016 Supp. 8-1012 was unconstitutional for the same reasons that K.S.A. 2016 Supp. 8-1025 was unconstitutional, and reversed and vacated Robinson's conviction on that count. ${ }^{111}$

\section{City of Dodge City v. Webb, 381 P.3d 464 (Kan. 2016)}

Full Case Citation: City of Dodge City v. Webb, 305 Kan. 351, 381 P.3d 464 (2016).

2016 CPS Section: II.G.3. - Searches and the Fourth Amendment / Technology and Searches / Chemical Drug Tests

\section{Summary:}

Defendant Webb was convicted of driving under the influence after the trial court denied his motion to suppress evidence of his blood alcohol content obtained from a breath test. ${ }^{112}$ The arresting officers threatened to get a warrant for a blood draw if Webb did not consent to the breath test. ${ }^{113}$ While Webb initially refused the breath test, after being instructed that the officers would obtain a warrant for a blood draw if he refused, Webb consented to the breath test.

102 K.S.A. 2016 Supp. 8-1012.

103 Id.

104 Robinson, 55 Kan. App. 2d at 209, 410 P.3d at 923. -2.

105 State v. Ryce, 303 Kan. 899, 368 P.3d 342 (2016) [hereinafter Ryce I]; State v. Ryce, 306 Kan. 683 , 396 P.3d

711 (2017) [hereinafter Ryce II]; see also infra fns. 57-68 and accompanying text.

106 Robinson, 55 Kan. App. 2d at 211, 410 P.3d at 925.

107 Id. (citing Ryce I, 303 Kan. at 699-700).

108 Id. at 223, 410 P.3d at 931.

109 Id. at 218-223, 410 P.3d at 929-931.

$110 I d$.

111 Id.

112 City of Dodge City v. Webb, 305 Kan. 351, 351-52, 381 P.3d 464, 466 (2016).

113 Id. 
Webb argued that, because of the threat to obtain a warrant for the blood draw, his consent was not lawfully obtained under the Kansas informed consent statute. ${ }^{114}$ However, the Kansas Supreme Court held that law enforcement officers are statutorily entitled to obtain a warrant for a blood draw from a driver who refuses a breath test, so long as the warrant is supported by probable cause. ${ }^{115}$ Because the warrant in this case was supported by probable cause, the breath test was not unlawfully coerced and the evidence was admissible. ${ }^{116}$ The court's decision overruled the Hoeffner decision from 2014. ${ }^{117}$

\section{Note:}

This case is included to reflect a change in law from Hoeffner, cited in the 2016 Criminal Procedure Survey, which was not included in the 2017 Supplement.

State v. Nece, 396 P.3d 709 (Kan. 2017)

Full Case Citation: State v. Nece, 306 Kan. 679, 396 P.3d 709 (2017).

2016 CPS Section: II.G.3. - Searches and the Fourth Amendment / Technology and Searches / Chemical Drug Tests

\section{Summary:}

Law enforcement officers suspected Nece of driving under the influence and gave him an "informed consent advisory." 118 The advisory stated that if Nece refused to a breath test for blood alcohol content he may be charged with the separate crime of refusing to consent to such a test. ${ }^{119}$ The Kansas Supreme Court held that, in the light of its holding in State v. Ryce, ${ }^{120}$ 'Nece's consent was unduly coerced because, contrary to the informed consent advisory, the State could not have constitutionally imposed criminal penalties if Nece had refused to submit to breath-alcohol testing." 121 Therefore, consent to a breath-alcohol test pursuant to an advisory that threatens non-submission with criminal penalties is considered coerced, and evidence resulting from such coerced consent is inadmissible. ${ }^{122}$

114 See K.S.A. 2011 Supp. 8-1001. See also Hoeffner v. Kan. Dept. Revenue, 50 Kan. App. 2d 878, 335 P.3d 684 (2014) (holding that a breath test consented to under threat of a warrant for a blood draw violates the implied consent statue).

115 Webb, 305 Kan. at 356-57, 381 P.3d at 469.

116 Id. at 358,381 P.3d at 470 .

117 See Hoeffner, 50 Kan. App. 2d at 886-889, 335 P.3d at 691-92.

118 State v. Nece, 306 Kan. 679, 679-80, 396 P.3d 709, 709-10 (2017).

119 Id., 396 P.3d at 710.

120 State v. Ryce, 306 Kan. 682, 396 P.3d 711 (Kan. 2017); see infra fns. 57-68 and accompanying text.

121 Nece, 306 Kan. at 680, 396 P.3d at 710.

122 The Kansas Supreme Court arrived at the same holding in State v. Nece, 303 Kan. 888, 367 P.3d 1260 (2016); the case was re-heard in the light of Birchfield v. N. Dakota, 136 S.Ct. 2160 (2016). 


\section{SEIZURES}

\section{United States v. Thompson, 866 F.3d 1149 (10th Cir. 2017)}

Full Case Citation: United States v. Thompson, 866 F.3d 1149 (10th Cir. 2017)

2016 CPS Section: III.B.1. - Seizures / Types of Seizures and Reasonability / Seizure of Items

\section{Summary:}

Defendant, Thompson, appealed his conviction and sentence, contending that the district court erred in admitting cell-service location information ("CSLI") obtained without a warrant. ${ }^{123}$ Thompson argued that the Fourth Amendment requires the government to produce a warrant before obtaining a cell-phone user's historical CSLI. ${ }^{124}$ The Tenth Circuit Court of Appeals affirmed the district court's decision to admit the CSLI. ${ }^{125}$

This is the first time the Tenth Circuit has confronted this issue. The Tenth Circuit follows four other circuits in rejecting Thompson's position by emphasizing the distinction that historic CSLI is collected by third-party service providers for their own business purposes, not the government. ${ }^{126}$ Further, like a pen register, CSLI is not a record of conversations between individuals, but is a record of the transmission of data that occurs to facilitate those conversations. ${ }^{127}$ As such, the Tenth Circuit Court of Appeals held that cell-phone users lack a reasonable expectation of privacy in their historic CSLI. ${ }^{128}$

State v. Maier, No. 115,248, 2017 WL 4216264 (Kan. Ct. App. Sept. 22, 2017)

Full Case Citation: State v. Maier, No. 115,248, 2017 WL 4216264 (Kan. Ct. App. Sept. 22, 2017).

2016 CPS Sections: III.B.2. - Seizures / Types of Seizures and Reasonability / Seizure of Persons

\section{Summary:}

The State challenged the district court's suppression of Maier's post-Miranda statements made after being arrested pursuant to an arrest warrant. ${ }^{129}$ Officers discovered Maier's outstanding arrest warrant after unlawfully entering his hotel room to search for his girlfriend. ${ }^{130}$ However, the Kansas Court of Appeals reversed the district court's decision to suppress Maier's statements

United States v. Thompson, 866 F.3d 1149, 1152 (10th Cir. 2017).

24 Id.

125 Id. at 1160.

126 Id. at $1154-55$.

127 Id. at 1158.

128 Id. at 1160.

129 State v. Maier, No. 115,248, 2017 WL 4216264, at*1 (Kan. Ct. App. Sept. 22, 2017).

$130 I d$. at $* 2-5$. 
after determining the discovery of Maier's arrest warrant broke the casual chain between the unconstitutional entry of the hotel room and Maier's post-Miranda statements. ${ }^{131}$

The Kansas Court of Appeals focused on United States Supreme Court case Utah v. Strieff, which held that an officer's discovery of a valid, preexisting arrest warrant and the finding that the officer did not participate in any flagrantly unlawful police misconduct was enough to break the casual link between an unconstitutional stop and the discovery of evidence. ${ }^{132}$ By relying on Strieff, the Kansas Court of Appeals refused to rely on Kansas case State v. Moralez, "which found that a warrant is of minimal importance in an attenuation analysis." 133

\section{State v. Lewis, 399 P.3d 250 (Kan. Ct. App. 2017)}

Full Case Citation: State v. Lewis, 54 Kan. App. 2d 263, 399 P.3d 250 (2017).

2016 CPS Section: III.B.2.b. - Seizures / Types of Seizures and Reasonability / Seizure of Persons / Detentions During Traffic Stops

\section{Summary:}

Defendant, Lewis, filed a motion to suppress evidence seized from his vehicle by contending that the police unreasonably prolonged his traffic stop to obtain a dog sniff which led to the discovery of cocaine. ${ }^{134}$ The officer wrote Lewis a traffic ticket and checked for any outstanding warrants. ${ }^{135}$ However, the K-9 unit arrived shortly after and the dog sniff that led to the discovery of the cocaine occurred about five minutes after the completion of the traffic stop. ${ }^{136}$ The trial court denied Lewis's motion to suppress the cocaine. ${ }^{137}$

On appeal, the Kansas Court of Appeals disagreed with the trial court's holding, determining that the officer unreasonably prolonged Lewis's traffic stop in violation of Rodriguez v. United States, which states that a dog sniff cannot prolong the stop beyond the time necessary to accomplish the original purpose of issuing a traffic citation. ${ }^{138}$ The court focused on the five minute delay following the completion of the traffic stop and the start of the dog sniff, finding this delay unreasonably prolonged the traffic stop to conduct the dog sniff. ${ }^{139}$ The court also determined that the officer artificially added time to the traffic stop to "stall" for the K-9 unit to arrive. ${ }^{140}$ Thus, the court reversed Lewis's conviction and remanded with instructions to grant his motion to suppress evidence. ${ }^{141}$

31 Id. at $* 11$.

132 Id. at *7-8; Utah v. Strieff, 136 S. Ct. 2056, 2063 (2016).

133 Maier, 2017 WL 4216264, at *7 (citing State v. Moralez, 297 Kan. 397, 415, 300 P.3d 1090, 1102 (2013)).

134 State v. Lewis, 54 Kan. App. 2d 263, 265, 399 P.3d 250, 253 (2017).

135 Id. at 278,399 P.3d at 261 .

$136 I d$. at 281,399 P.3d at 262-63.

$137 I d$. at 269,399 P.3d at 253.

$138 I d$. at 271, 282-84, 399 P.3d at 257, 263-64.

139 Id. at 281-84, 399 P.3d at 262-63.

$140 I d$. at 282,399 P.3d at 263.

141 Id. at 284, 399 P.3d at 264. 
Full Case Citation: State v. Glover, 54 Kan. App. 2d 377, 400 P.3d 182 (2017).

2016 CPS Section: III.B.2.b. - Seizures / Types of Seizures and Reasonability / Seizure of Persons / Detentions During Traffic Stops

\section{Summary:}

Defendant Glover filed a motion to suppress evidence obtained as a result of a traffic stop, arguing that the officer initiated the stop without the necessary reasonable suspicion to believe a crime had been, was being, or was going to be committed. ${ }^{142}$ Glover argued that the officer's reliance only on evidence showing that the registered owner of the vehicle had a suspended driver's license is insufficient to support a reasonable inference that the owner of the vehicle is the person driving the vehicle. ${ }^{143}$ The district court granted Glover's motion to suppress. ${ }^{144}$

On appeal, the Kansas Court of Appeals disagreed, and reversed and remanded the district court's decision to grant Glover's motion to suppress. ${ }^{145}$ Because Kansas courts had never confronted this narrow issue, the court followed guidance from other jurisdictions, holding that "an officer has reasonable suspicion to initiate a vehicle stop when (1) the officer knows that the registered owner of a vehicle has a suspended license and (2) the officer is unaware of any evidence or circumstances which indicate that the owner is not the driver of the vehicle."146 Using this test, the court determined that the officer properly initiated the traffic stop to investigate whether Glover was driving his vehicle in violation of the law. ${ }^{147}$

State v. Dannebohm, No. 116,981, 2017 WL 3447883 (Kan. Ct. App. Aug. 11, 2017)

Full Case Citation: State v. Dannebohm, No. 116,981, 2017 WL 3447883 (Kan. Ct. App. Aug. 11, 2017).

2016 CPS Section: III.C. - Seizures / Standing to Object to Seizure

\section{Summary:}

The State appealed the district court's finding that defendant Dannebohm had standing to pursue a motion to suppress evidence that he had methamphetamine inside a safe located in the apartment of a close friend, Tracy. ${ }^{148}$ The Kansas Court of Appeals reversed and held

${ }^{42}$ State v. Glover, 54 Kan. App. 2d 377, 378, 400 P.3d 182, 184 (2017).

43 Id. at 378,400 P.3d at 184.

144 Id. at 378,400 P.3d at $184-85$.

$145 I d$. at 386,400 P.3d at 188 .

$146 I d$. at 382,400 P.3d at 186.

${ }^{147} I d$. at 385,400 P.3d at 188.

148 State v. Dannebohm, No. 116,981, 2017 WL 3447883, at*1 (Kan. Ct. App. Aug. 11, 2017). 
Dannebohm lacked standing because he lacked a reasonable expectation of privacy when police searched Tracy's apartment. ${ }^{149}$

The court distinguished the facts of the case from those in State v. Talkington, a seminal Kansas case concerning standing to object to a seizure. ${ }^{150}$ In Talkington:

The court determined that the defendant did have an expectation of privacy in his host's home because: (1) the defendant's visit was not commercial in nature; (2) the defendant had been at his host's home for a few hours before the officers arrived; (3) the defendant and his host had been friends for 7 or 8 years; (4) the defendant and host worked on cars and mopeds together; and (5) the defendant visited whenever he was in town, including the previous week. ${ }^{151}$

The court in Dannebohm noted that, like the defendant in Talkington, Dannebohm had been friends with Tracy for several years, regularly visited her at her apartment for noncommercial reasons, had been at her apartment earlier on the day of the search, and kept personal possessions at the apartment. ${ }^{152}$ The key difference, the court determined, was that Dannebohm was not at Tracy's home at the time of the search and was thus not a current guest at that time so as to have a reasonable expectation of privacy. ${ }^{153}$ Moreover, Dannebohm's connection to the apartment was insufficient to support a reasonable expectation of privacy when he was not a current guest. For example, Dannebohm did not have a key to the apartment, did not appear to have permission to enter the apartment in Tracy's absence or to exclude others from entering the apartment, had never stayed the night, and had never left his car at the apartment. ${ }^{154}$

Dannebohm's holding expanded upon Talkington's standing analysis by drawing the distinction between a person's expectation of privacy when present and not present at the time of a police search. The case also provides important factual considerations for determining when a person, who is not a guest at the time of a search, has a reasonable expectation of privacy in another's home.

\section{State v. Mattox, 390 P.3d 514 (Kan. 2017)}

Full Case Citation: State v. Mattox, 305 Kan. 1015, 390 P.3d 514 (2017).

2016 CPS Section: III.D.2 - Seizures / Fifth \& Sixth Amendment Issues / Applicability of the Sixth Amendment

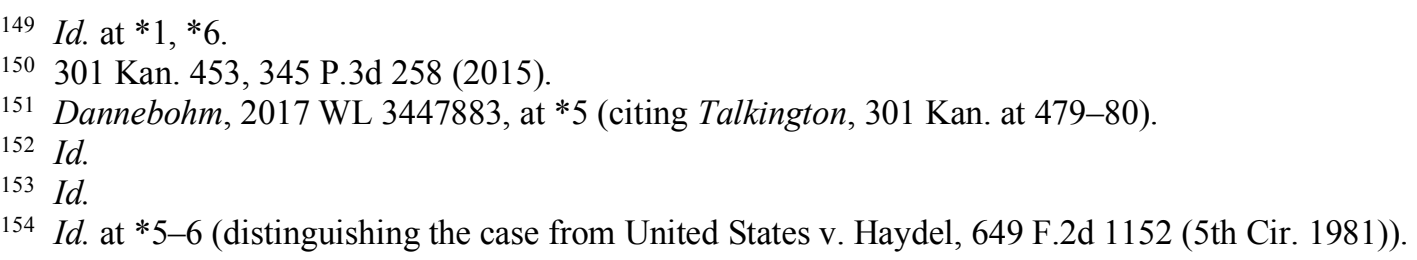




\section{Summary:}

Defendant, Mattox, appealed his conviction for first-degree murder, aggravated kidnapping, and aggravated robbery. ${ }^{155}$ Mattox, who asserted a mental disease or defect defense, argued, in part, that his Sixth Amendment right to counsel was violated when the State's expert witness conducted a psychological evaluation on him without his counsel present. ${ }^{156}$ While the court noted that the U.S. Supreme Court had not resolved the particular issue, it held that Mattox's Sixth Amendment rights were not violated because the State's psychiatric examination was not a "critical stage" of the proceedings against him. ${ }^{157}$ The court relied on its earlier decision in Brown and cited a plethora of state and federal courts that had held similarly. ${ }^{158}$ The court also affirmed the district court's holdings that (1) Mattox's question, "You all care if I get a lawyer in here?" was too ambiguous to have invoked his right to counsel during the police interrogation in which he confessed; and (2) his Miranda waiver and confession were knowing and voluntary despite evidence suggesting possible psychotic functioning, because there was substantial competent evidence supporting the district court's determinations. ${ }^{159}$ Mattox is notable because it confirms that defendants in Kansas do not have a right to counsel during psychological evaluations, and provides an overview of Kansas's approach to the right to counsel, Miranda waivers, and the right against self-incrimination.

State v. Brown, 387 P.3d 835 (Kan. 2017)

Full Case Citation: State v. Brown, 305 Kan. 674, 387 P.3d 835 (2017).

2016 CPS Section: III.D.3.f. - Seizures / Fifth \& Sixth Amendment Issues / Miranda Warnings \& Interrogations / Invocation of the Right to Counsel

\section{Summary:}

Defendant Antonio Brown challenged his convictions of "felony murder, two counts of child abuse, and one count of interference with a law enforcement officer." 160 Defendant argued that his convictions should be reversed because the district court admitted incriminating statements that he made after invoking his right to counsel. ${ }^{161}$ The Kansas Supreme Court held

\footnotetext{
155 State v. Mattox, 305 Kan. 1015, 1016, 390 P.3d 514, 519 (2017).

156 Id. at 1031,390 P.3d at 528.

157 Id. at $1053-54,390$ P.3d at 541.

158 Id. at 1054-55, 390 P.3d at 541 (citing State v. Brown, 235 Kan. 688, 690, 681 P.2d 1071, 1073 (1984)).

159 Mattox, 305 Kan. at 1036-45, 390 P.3d at 530-36.

160 State v. Brown, 305 Kan. 674, 675, 387 P.3d 835, 840 (2017).

$161 I d$. at 675,387 P.3d at 840 . Brown also argued that his convictions should be reversed because the district court did not give an instruction on a lesser included offense and that the evidence was insufficient to support the conviction of interference with a law enforcement officer. $I d$. The Kansas Supreme Court found that the district court acted properly in not giving a lesser included offense because state law did not recognize a lesser included offense and the Defendant's constitutional arguments failed. Id. at 687-88, 387 P.3d at 847-48. The Kansas Supreme Court also found that the evidence supports the Defendant's conviction of interference with a law enforcement officer. $I d$. at 692, 387 P.3d at 850 .
} 
that the defendant "unequivocally" invoked his right to counsel when he asked for assistance in reaching his lawyer and when he attempted to call his attorney during the interview. ${ }^{162}$ The issue here was whether the defendant reinitiated the questioning after invoking his right to counsel, which would not be a deprivation of his Sixth Amendment right. ${ }^{163}$

The standard for determining whether a suspect waived his previously invoked right to counsel requires the court to determine "whether the accused (1) initiated further discussions with police and (2) knowingly and intelligently waived the previously asserted right."164 The Kansas Supreme Court focused on the first element of the test. The court stated that whether a suspect wanted to reinitiate "turns on 'both the content and context' of the statement when "viewed from the perspective of a reasonable officer.""165 After the defendant tried and failed to reach his lawyer, the defendant stated that "he understood 'fully' his rights," he "would talk without an attorney present," and he "had "nothing to hide.""166 The court held that, by these statements, the defendant reinitiated the questioning and, thereby, waived his previously asserted right to counsel "knowingly and intelligently."167

\section{United States v. Yepa, 862 F.3d 1252 (10th Cir. 2017)}

Full Case Citation: United States v. Yepa, 862 F.3d 1252 (10th Cir. 2017).

2016 CPS Section: III.D.3.f. - Seizures / Fifth \& Sixth Amendment Issues / Miranda Warnings \& Interrogations / Invocation of the Right to Counsel

\section{Summary:}

Defendant Yepa was convicted of first-degree felony murder in a New Mexico federal district court. ${ }^{168}$ Defendant challenged that conviction on the grounds that his incriminating statements "were the incriminating product of unlawful interrogation."169 The defendant, who was arrested at his house, was advised of his Miranda rights and stated he wanted a lawyer. ${ }^{170}$ Subsequently, he was taken to the Jemez Pueblo Police Department and FBI agents obtained a warrant to search his home and body for evidence of murder. ${ }^{171}$ The search of the defendant's body took "50 minutes, was audio-recorded; [and] the recording was later transcribed." 172 The Tenth Circuit Court of Appeals stated that "[w] hat is striking from the recording is that

${ }_{162} I d$. at 681,387 P.3d at 844.

$163 I d$. at 682,387 P.3d at 844 .

$164 I d$. at 683, 387 P.3d at 844 (quoting State v. Walker, 276 Kan. 939, 947, 80 P.3d 1132, 1138 (2003)).

${ }^{165} \mathrm{Id}$. at 683, 387 P.3d at 845 (quoting United States v. Straker, 800 F.3d 570, 623, 419 U.S. App. D.C. 210 (D.C. Cir. 2015)).

166 Id. at 683,387 P.3d at 845 .

167 Id.

168 United States v. Yepa, 862 F.3d 1252, 1253 (10th Cir. 2017).

169 Id. at 1257.

170 Id. at 1253.

${ }^{171}$ Id. at 1253-54.

172 Id. at 1254. 
Defendant's incriminating statements are scattered throughout, without any apparent connection to what is going on at the time, and that the officers are focused on performing their search, rarely reacting in any way to what Defendant says about the offense." $" 173$

The defendant sought to suppress the statements he made during the body search. ${ }^{174}$ The Court of Appeals stated that for the Defendant to succeed at suppressing those statements, he must prove they "were (1) the result of words or actions of law-enforcement officers (2) that constituted interrogation." 175 The court held that the defendant failed to meet this burden. ${ }^{176}$ First, the court determined the search itself was not an interrogation because it was a common action of arrest and custody. ${ }^{177}$ The Court of Appeals agreed with the district court that the Defendant's statements "were spontaneous and were not the result of interrogation." 178 The court stated that questions regarding who the defendant was referring to "were simply neutral efforts to clarify [his] spontaneous, volunteered statements, and did not constitute interrogation."179 The court also stated that the question "who were you with?" could have appeared to be pressing the point, but they did not need to address whether those could be considered interrogation because the "Defendant never answered the questions." 180 The Court of Appeals, finding no error in admitting the statements, affirmed the Defendant's conviction. ${ }^{181}$

State v. Guein, 388 P. 3d 194 (Kan. 2017)

Full Case Citation: State v. Guein, 53 Kan. App. 2d 394, 388 P. 3d 194 (2017), review granted, 2017 Kan. LEXIS 813 (Kan., Sept. 29, 2017).

2016 CPS Section: III.D.3.g. - Seizures / Fifth \& Sixth Amendment Issues / Miranda Warnings \& Interrogations / Statements Made During Police Interrogation

\section{Summary:}

Defendant Guein appealed his conviction for two drug-related offenses claiming that the confession he made to police while in custody was involuntary and should not have been admitted at trial. ${ }^{182}$ Police detained Guein because of a strong marijuana smell coming from his car. ${ }^{183}$ The officer handcuffed him and walked him to the police car. ${ }^{184}$ Before reading him his Miranda rights,

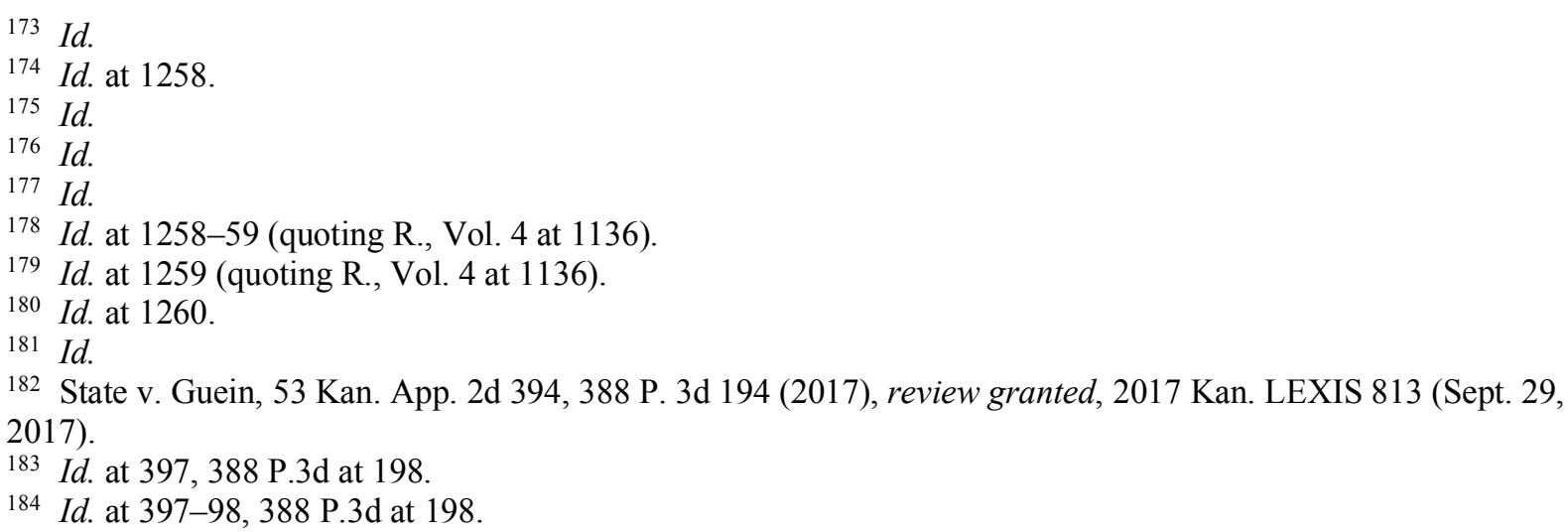


the officer told Guein not to "fuck with him" several times, indicating that if Guein cooperated, he would have nothing to worry about. ${ }^{185}$ Guein was later read his Miranda rights after about 10 minutes in the police car. ${ }^{186}$ The district court denied Guein's request to have his pre- and postMiranda statements suppressed, holding that the officers were justified in their statements and that Guein had voluntarily waived his rights. ${ }^{187}$

The Kansas Court of Appeals reversed, holding Guein's post-Miranda statements should have been suppressed because the officer's warning not to "fuck" with him constituted a threat and negated the Miranda warning. ${ }^{188}$ The court used the standard laid out in State $v$. Randolph to assess whether the officer's statements were coercive. ${ }^{189}$ The court held that "[t]aken in context, a reasonable person would conclude that [the officer] made an implied threat of physical violence and connected it to answering the questions [the officer] would soon be asking in a way that conformed with [the officer's] understanding." 190 The statements were made only after Guein's hands were handcuffed. ${ }^{191}$ Guein was also left in the police car for 10 minutes before he was given his Miranda warning. ${ }^{192}$

While the court took special care to quote the officer's vulgar language, it also went out of its way to state that the vulgar language was not the deciding factor in this case:

The use of profanity here simply amplified the serious nature of the statements being made ... It's only because that language was accompanied by words conveying additional messages - that [the officer] was going to be asking more questions, that [the officer] expected cooperation when he did so, and that [the officer] might "fuck with" Guein if he didn't cooperate - that tip the balance here strongly in Guein's favor when we consider whether the State proved the statements were made voluntarily. ${ }^{193}$

\section{PRe-Trial ISSUES}

State v. Mosby, No. 115,598, 2017 WL 2610765 (Kan. Ct. App. 2017)

Full Case Citation: State v. Mosby, No. 115,598, 2017 WL 2610765 (Kan. Ct. App. 2017).

Sections: IV.A.1. - Pre-Trial Issues / Formal Charges / Charging Instruments: Complaint, Information, and Indictment

85 Id. at 397-98, 388 P.3d at 198.

186 Id. at 399, 388 P.3d at 199.

187 Id. at 401-02, 388 P.3d at 200.

188 See generally id. at 408-15, 388 P.3d at 204-08.

189297 Kan. 320, 301 P.3d 300 (2013).

190 Guein, 53 Kan. App. 2d at 410, 388 P. 3d at 205.

$191 I d$. at 410, 388 P.3d at 205.

192 Id. at 411, 388 P.3d at 205.

193 Id. at 411-12, 388 P.3d at 206. 


\section{Summary:}

Defendant, Mosby, challenged his sentence on the grounds that "[ $t]$ he State did not provide adequate notice of the theft charge against him because the charging document did not list all of the items the State alleged at trial he stole."194 The charging document alleged the defendant stole property "including but not limited to 20 specific items." 195 However, the defendant was unaware of each "specific item" the State alleged he stole and claimed he was therefore unable "to prepare an adequate defense."196 The court excused his failure to raise the issue below because the defendant's fundamental Due Process rights were denied by the lack of notice provided by the charging document. ${ }^{197}$ The court's holding in this case clarified the due process/notice safeguard that protects defendants against insufficient pleadings retained by the Kansas Supreme Court after State v. Dunn. ${ }^{198}$ In Dunn, the court noted that insufficiency to provide the defendant with adequate due process and notice is one of three avenues to challenge a charging document. ${ }^{199}$

Brown v. State, No. 116,744, 2017 WL 4455306 (Kan. Ct. App. 2017)

Full Case Citation: Brown v. State, 404 P.3d 358 (Kan. Ct. App. 2017).

\section{CPS Section:}

- IV.A.2. - Pre-Trial Issues / Formal Charges / Bill of Particulars

- IV.B.1. - Pre- Trial Issues / Initial Appearances / Speedy Public Trial

\section{Summary:}

The Defendant, Brown, wished to plead guilty to the State's charges ${ }^{200}$ The trial court requested a proffer of evidence to support his plea. ${ }^{201}$ However, the Defendant did not wish to offer additional evidence, but to plead guilty only to the facts alleged in the State's charging documents. ${ }^{202}$ Later, the trial court plead not guilty on his behalf. ${ }^{203}$ On appeal, the Defendant argued that "because K.S.A. 22-3201 requires a charging document to include 'the essential facts constituting the crime charged,' his charging document should have been sufficient to support his guilty pleas."204 However, the court held that K.S.A. 22-3201 does not apply to pleas, but instead applies to "the sufficiency of charging documents in the context of due process." 205 This

94 State v. Mosby, No. 115,598, 2017 WL 2610765, at *6 (Kan. Ct. App. 2017).

$95 I d$. at $* 2$.

196 Id. at $* 2, * 6-7$.

197 Id. at $* 6-13$.

198304 Kan. 773, 375 P.3d 332 (2016).

199 Id. at 773,378 P.3d at 358 .

200 Brown v. State, No. 116,744, 2017 WL 4455306, at *2 (Kan. Ct. App. 2017).

201 Id. at *3.

202 Id. at *3-5.

203 Id. at *5-6.

$204 I d$. at $* 25-26$.

$205 I d$. at *26-27. 
holding clarified that K.S.A. 22-3201 was drafted to create a remedy when a defendant's due process rights are violated, not to support pleas.

State v. Robinson, 399 P.3d 194 (Kan. 2017)

Full Case Citation: State v. Robinson, 306 Kan. 1012, 399 P.3d 194 (2017).

2016 CPS Section: IV.B.1. - Pre- Trial Issues / Initial Appearances / Speedy Public Trial

\section{Summary:}

After a conviction for aggravated burglary, aggravated theft, and criminal damage to property, Robinson appealed his verdict and subsequent affirmation by the Kansas Court of Appeals, claiming seven errors at trial. ${ }^{206}$ At issue in the case was his assertion that his speedy trial rights under K.S.A. 22-3402 were violated. ${ }^{207}$

Robinson asserted a violation of his speedy trial rights because the district court granted the State an improper continuance. ${ }^{208}$ The State requested this continuance because a material witness - a medical doctor - was unavailable due to a "traveling rotation" that would have placed him out of the area during the scheduled trial dates. ${ }^{209}$ The trial court granted the continuance under K.S.A. 22-3402(5)(c), extending the trial schedule by 90 days, which Robinson asserted was beyond his speedy trial time. ${ }^{210}$

Robinson asserted the continuance was improper because the medical doctor was not truly unavailable, only inconvenienced. ${ }^{211}$ Relying on State v. George, Robinson asserted that the state failed to provide sufficient evidence that the doctor was truly unavailable. ${ }^{212}$ The Court agreed, noting that the record was "slim," and that the State had produced no evidence to back up their claim of unavailability. ${ }^{213}$

However, Robinson's assertions ultimately failed because his counsel did not timely object to the continuance request. ${ }^{214}$ While he did object generally to the request for a continuance, he did not specifically object to the doctor's unavailability, even when offered an opportunity to do so. ${ }^{215}$ Thus, the Court rejected his claim of speedy trial error because the trial court did not abuse its discretion in granting the continuance in the absence of a preserved objection. $^{216}$

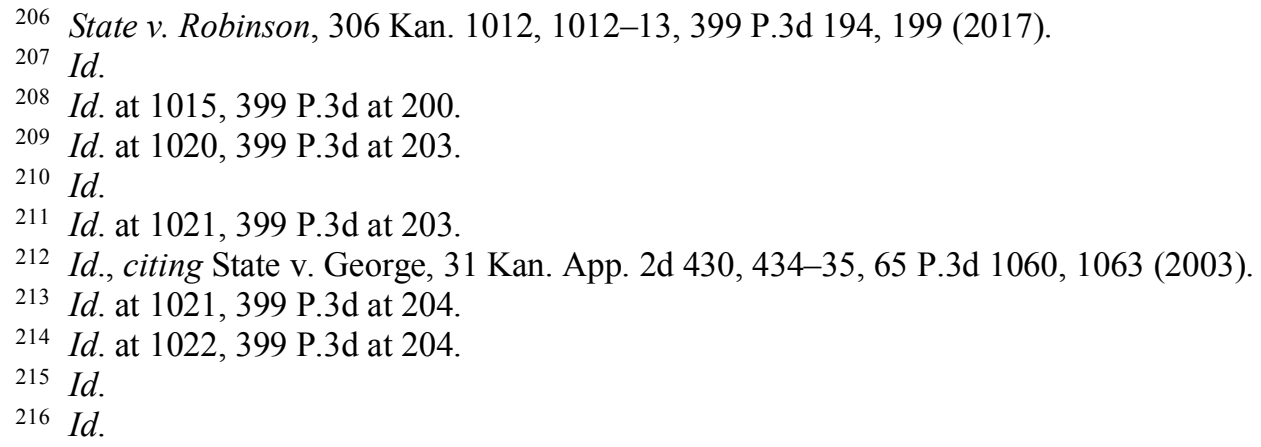


This case emphasizes two points for attorneys in similar situations. First, if declaring a witness unavailable, counsel should state with specificity the reasons the witness qualifies for unavailability under the Kansas Rules of Evidence. Second, when preserving an objection for appeal, a general objection is not sufficient: a record must be made of exactly which claims or assertions a party is objecting to.

State v. McDaniel, 395 P.3d 429 (Kan. 2017)

Full Case Citation: State v. McDaniel, 306 Kan. 595, 395 P.3d 429 (2017).

2016 CPS Section: IV.D. 1. - Pre-Trial Issues / Preliminary Hearing / Right to Preliminary Hearing

\section{Summary:}

In State v. McDaniel, Defendant, McDaniel, challenged his forced absence at several stages of his preliminary hearing. ${ }^{217}$ Prior to his preliminary hearing, McDaniel filed a pro se motion to dismiss his case. ${ }^{218}$ During the hearing, his counsel refused to present his motion, and the judge refused to listen to McDaniel present it because he already had counsel. ${ }^{219} \mathrm{McDaniel}$ then sought to present an oral motion to remove his counsel, which both the judge and McDaniel's attorney told him had to be in writing. ${ }^{220}$ After the hearing, the judge closed the record and sent the court into recess. ${ }^{221}$ However, after McDaniel left, the judge reopened the hearing record to record his observations regarding McDaniel's interactions with his attorney. ${ }^{222}$ Kansas courts recognize that while defendants have a constitutional right "to be present at every critical stage of the proceedings," this "right is not unqualified."223 Specifically, defendants should be present at "any stage of the criminal proceeding that is critical to its outcome if the defendant's presence would contribute to the fairness of the procedure."224

The Kansas Supreme Court ruled that a defendant does have the right to be at the reopening of the preliminary hearing record. ${ }^{225}$ The court held that since "the issue addressed at the proceeding bore on [McDaniel's] opportunity to defend himself at trial. . . his participation was necessary to fairly resolve it." 226 The State attempted to argue that this did not constitute a critical stage of the proceeding, but the court noted that the only reason for the judge opening the record back up was "to preserve the observation for others who might later review whether McDaniel deserved a new attorney." 227 Thus, the court concluded that McDaniel's constitutional

\footnotetext{
State v. McDaniel, 306 Kan. 595, 600-01 395 P.3d 429, 437 (2017).

218 Id. at $597-98,395$ P.3d at $435-36$.

$219 I d$. at 598,395 P.3d at 436.

$222 I d$. at598-600, 395 P.3d at 436-37.

${ }^{223}$ Id. at $600-03,395$ P.3d at $437-39$.

${ }^{224}$ State v. Calderon, 270 Kan. 241, 245, 13 P.3d 871, 875 (2000).

${ }_{225}$ McDaniel, 306 Kan. at $602-03,395$ P.3d at 439.

${ }^{226} I d$. at 601,395 P.3d at 438.
}

$220 \mathrm{Id}$.

${ }^{221}$ Id.

${ }^{227}$ Id. 
and statutory rights were violated. However, the court concluded that the violation of McDaniel's right constituted a harmless error. ${ }^{228}$

Wahl v. State, No. 114,888, 2017 WL 3668917 (Kan. Ct. App. Aug. 25, 2017)

Full Case Citation: Wahl v. State, No. 114,888, 2017 WL 3668917 (Kan. Ct. App. Aug. 25, 2017).

2016 CPS Section: IV.D.2. - Pre-Trial Issues / Preliminary Hearing / Self Representation for a Preliminary Hearing

\section{Summary:}

In Wahl v. State, the Defendant Wahl had problems with several of his previouslyappointed attorneys. ${ }^{229}$ Eventually, Wahl filed a pro se motion requesting an evidentiary hearing where he could present additional claims against one of his past appointed attorneys. ${ }^{230}$ The court granted his request and appointed new counsel to represent Wahl. ${ }^{231}$ Before the evidentiary hearing, a preliminary hearing ultimately had the characteristics of an evidentiary hearing, so the judge determined that a formal evidentiary hearing was unnecessary. ${ }^{232}$ Wahl's attorney agreed. $^{233}$ After the hearing, the court ruled that Wahl had not adequately shown ineffective assistance of counsel. ${ }^{234}$ After the ruling, Wahl mailed a pro se objection regarding the denial of an evidentiary hearing. ${ }^{235}$ Further, Wahl appealed the decision of the court, stating that the denial of the evidentiary hearing violated due process. ${ }^{236}$ Specifically, Wahl claimed, "he was deprived of notice that the entirety of [his] claim was to be determined in the hearing." 237

The Kansas Court of Appeals ruled that Kansas law does not allow for this type of hybrid representation and therefore the Wahl was not denied due process since he was represented by counsel. ${ }^{238}$ The court pointed to the fact that Wahl was represented by counsel at the hearing and that "[a] criminal defendant does not have an absolute right to both self-representation and the assistance of counsel." 239 The court further stated that "a defendant who is represented by counsel cannot dictate matters such as what witnesses to call or what motions to call. ${ }^{240}$ The

\footnotetext{
228 Id. at 598-600, 395 P.3d at 437.

229 Wahl v. State, No. 114,888, 2017 WL 3668917, at*1 (Kan. Ct. App. Aug. 25, 2017).

$230 I d$. at $* 2$.

231 Id.

232 Id.

$233 I d$.

234 Id.

235 Id.

236 Id.

237 Id. at $* 3$.

238 Id. at *4 (citing State v. McKessor, 246 Kan. 1, 12, 785 P.2d 1332, 1339-40 (1990)).

239 Id (citing State v. Ames, 222 Kan. 88, 100, 563 P.3d 1034, 1044-45 (1977) regarding hybrid representation and calling of witnesses).

${ }^{240} \mathrm{Id}$.
} 
court concluded that the state's hybrid representation rule did apply to pro se motions, therefore pro se motions generally do not carry any legal weight when the person is currently represented by counsel. ${ }^{241}$

State v. Johnson, No. 110,837, 2017 WL 4558235 (Kan. Ct. App. October 13, 2017)

Full Case Citation: State v. Johnson, No. 110,837, 2017 WL 4558235 (Kan. Ct. App. October 13, 2017).

2016 CPS Section: IV.F.1. - Pre-Trial Issues / Jurisdiction \& Venue / Jurisdiction

\section{Summary:}

Defendant Johnson appealed his conviction on two counts of criminal solicitation to commit first-degree murder of his former wife. ${ }^{242}$ Johnson was charged with three counts of criminal solicitation pursuant to K.S.A. 2016 Supp. 21-5303 based on his separate and distinct interactions with three different people. ${ }^{243}$ One of these interactions was with an undercover detective from the Olathe Police Department. ${ }^{244}$ Part of Johnson's interaction with the officer was a $\$ 3,000$ down payment that occurred in Missouri. ${ }^{245}$ Johnson claimed the Kansas criminal solicitation statute was unconstitutional for vagueness and that jurisdiction was lacking. ${ }^{246}$

Johnson raised these issues for the first time on appeal, but the appellate court determined it had jurisdiction because Johnson argued the statute was facially invalid, and not invalid applied to his facts alone. ${ }^{247}$ The court determined that the statute was constitutional and not vague because the term "encouraging" used in the statute (1) was "clear and unambiguous", ${ }^{248}$ (2) "[gave] fair warning of the proscribed conduct and adequately guards against arbitrary and unreasonable enforcement", ${ }^{249}$ and (3) was not an unreasonable restriction of First Amendment free speech rights. ${ }^{250}$

The court also determined that the part of the commission of the crime occurred in Missouri is irrelevant. ${ }^{251}$ Under Kansas law, a criminal defendant is subject to prosecution in the state if the crime is committed "wholly or partly within this state." 252

\footnotetext{
${ }^{241} I d$. at $* 4$.

${ }^{242}$ State v. Johnson, No. 110,837, 2017 WL 4558235, at*1 (Kan. Ct. App. Oct. 13, 2017).

243 Id. at *8.

$244 I d$. at $* 1-2$.

$245 I d$. at $* 3$.

$246 I d$. at $* 4, * 12$.

247 Id. at $* 5$.

$248 I d$. at $* 6$.

${ }^{249} I d$.

250 Id. at *7.

251 Id. at *12.

252 K.S.A. § 21-5106(a)(1).
} 
Full Case Citation: United States v. Trinh, No. 17-MJ-90007-GEB, 2017 WL 3675102 (D. Kan. Aug. 25, 2017)

2016 CPS Section: IV.F.1. - Pre-Trial Issues / Jurisdiction \& Venue / Jurisdiction

\section{Summary:}

The district court considered Defendant's motion to dismiss for lack of venue on her charge of promoting obscenity by recklessly transmitting obscene material. ${ }^{253}$ Defendant lived in Texas, but her boyfriend was a U.S. Army soldier stationed at Fort Riley, Kansas. ${ }^{254} \mathrm{He}$ sent her an obscene photograph by e-mail, which Defendant then forwarded to three of her boyfriend's coworkers. ${ }^{255}$ Defendant was charged in Kansas under the Assimilated Crimes Act which utilizes state law to fill in the gaps in federal law when a defendant commits an offense on property of exclusive federal jurisdiction that is only punishable by state law. ${ }^{256}$ To determine whether venue was proper, the district court looked to the intent of the Kansas "promotion of obscenity" statute to determine if it was intended to apply to material originating out of state. ${ }^{257}$

Under K.S.A. § 21-6401(a)(1), a person promotes obscenity when she recklessly "transmit[s]. . . any obscene material."258 The court determined that the act of "transmission" requires both a sender and a recipient, and that receiving the material is a "constituent and material element of the offense." 259 Therefore, under the Kansas statute, the court held jurisdiction was proper because the crime was partly committed within the state of Kansas. ${ }^{260}$

\section{State v. Beck, 406 P.3d 377 (Kan. 2017)}

Full Case Citation: State v. Beck, 307 Kan. 108, 406 P.3d 377 (2017).

2016 CPS Section: IV.J.1. - Pre-Trial Issues / Plea Agreements / Recent Plea Agreement Cases

\section{Summary:}

Beck entered into a plea agreement with the State and pled guilty to first-degree murder and attempted first-degree murder. ${ }^{261}$ In exchange for the pleas, the State agreed to "recommend to the sentencing court that the sentences be ordered to run concurrently."262 However, "despite

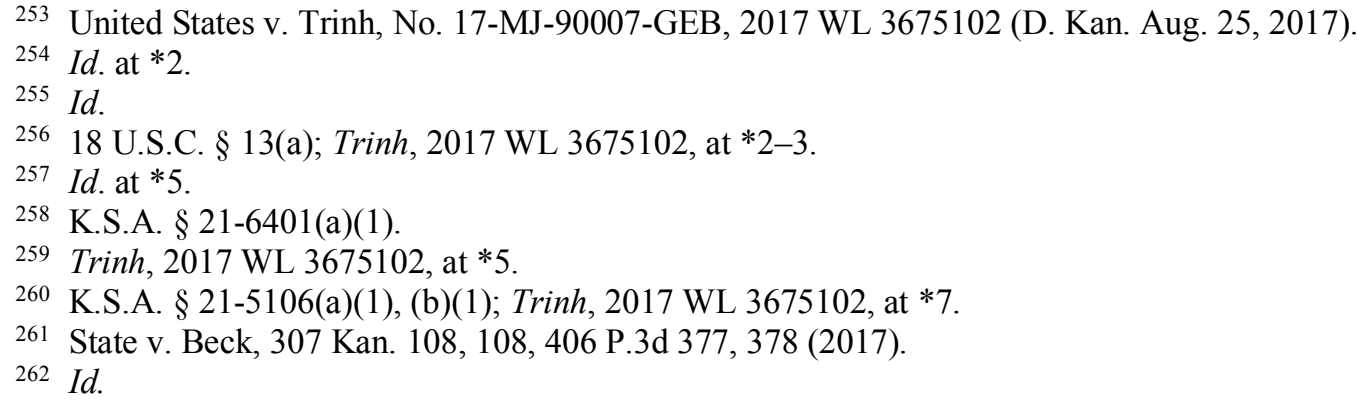


the parties' joint recommendation, the court decided to run the sentences consecutively rather than concurrently."263 Beck appealed, arguing that the "court erred when it refused to follow the plea agreement's recommendation."264

An abuse of the sentencing court's discretion occurs when the court's "decision is (1) arbitrary, fanciful, or unreasonable; (2) based on an error of law; or (3) based on an error of fact." 265 Beck argued that the district court's decision to run the sentences consecutively was arbitrary, fanciful, or unreasonable "because he accepted responsibility for his actions and spared the victim's family and the State from the pain and expense of trial."266 However, the Kansas Supreme Court held that the district court did not abuse its discretion, noting the district court's rationale that, given the severity of Beck's crimes, it would be a "travesty of justice" to run the sentences concurrently. ${ }^{267}$

\section{TRIAL RightS}

\section{United States v. Williston, 862 F.3d 1023 (10th Cir. 2017)}

Full Case Citation: United States v. Williston, 862 F.3d 1023 (10th Cir. 2017), cert. denied, 138 S. Ct. 436 (2017).

2016 CPS Section: V.A.2. - Trial Rights / Fifth Amendment Issues / Immunity

\section{Summary:}

Defendant Williston beat his girlfriend's daughter to death while she was at work. ${ }^{268}$ Months after the initial police report was filed, and while Williston was in an Oklahoma jail for a separate state-level charge, FBI agents served a grand jury subpoena on him relating to the murder of his ex-girlfriend's daughter. ${ }^{269}$ The subpoena included a rare "Advice of Rights" section, which advised Williston that he could "refuse to answer any question if a truthful answer to the question would tend to incriminate [him]." ${ }^{270}$ Williston duly attended the grand jury proceedings, and at questioning waived his right to answer non-incriminating questions, choosing instead to answer all questions. ${ }^{271}$ After large portions of his grand jury testimony were read during his seven-day trial, a jury found Williston guilty of the murder, and " $[\mathrm{t}]$ he district

Id.at 109, 406 P.3d at 378.

264 Id. at 110,406 P.3d at 378.

265 Id. (quoting State v. Mattox, 305 Kan. 1015, 1029-30, 390 P.3d 514, 527 (2017)).

$266 I d, 406$ P.3d. at 379.

267 Id.

268 United States v. Williston, 862 F.3d 1023, 1029 (10 ${ }^{\text {th }}$ Cir. 2017), cert. denied, 138 S. Ct. 436 (2017).

269 Id at 1028.

270 Id.

271 Id. at 1028-30. 
court sentenced [him] to life without parole," per 18 U.S.C. $§ 3559$ (d) for his crime against a child. ${ }^{272}$

On appeal to the $10^{\text {th }}$ Circuit Court of Appeals, Williston argued that his questioning before the grand jury violated his right against self-incrimination under the Fifth Amendment since he was not Mirandized or warned of his rights prior to the grand jury testimony. ${ }^{273}$ The court denied these complaints for two very important reasons. First, the court found that Williston was told "three times that he could refuse to answer any grand-jury question if he felt the answer would incriminate him," which provided sufficient notice given the context. ${ }^{274}$ Second, and most importantly, the court determined that witnesses testifying at grand jury proceedings are not read Miranda warnings because "grand-jury witnesses are not in custody while testifying, and that grand-jury questioning is not interrogation," so Miranda is not violated by coercion in these situations. ${ }^{275}$ The court went on to say granting such Miranda rights "would destroy a key part of the grand jury's investigative power. . . . This absolute right to remain silent ... would hobble the grand jury's ability to get to the bottom of crimes," so it refused to expand Miranda. ${ }^{276}$

Weaver v. Massachusetts, 137 S. Ct 1899 (U.S. 2017)

Full Case Citation: Weaver v. Massachusetts, 137 S. Ct 1899 (U.S. 2017).

2016 CPS Section: V.B.2.b. - Trial Rights / Sixth Amendment Issues / Trial by Jury / Jury Selection

\section{Summary:}

Defendant Weaver requested a new trial when defense counsel failed to object to the courtroom being closed to the public for two days during the jury selection process. ${ }^{277}$ Weaver claimed his attorney's failure to object constituted ineffective assistance of counsel, entitling him to a new trial. ${ }^{278}$

The pool of potential jury members for Weaver's trial was large and the assigned courtroom could not accommodate all the potential jurors, so the judge ordered the officer of the court to exclude all members of the public. ${ }^{279}$ When Weaver's mother and minister showed up to observe jury selection, they were turned away. ${ }^{280}$ Weaver's mother told defense counsel about the occurrence, but defense counsel told her this was constitutional. ${ }^{281}$

\footnotetext{
272 Id. at 1030 .

273 Id.

274 Id. at $1031-32$.

275 Id. at 1032.

276 Id. at $1032-33$.

277 Weaver v. Massachusetts, 137 S. Ct. 1899, 1905 (U.S. 2017).

278 Id.

${ }_{279} I d$.

$280 I d$. at 1906.

${ }^{281} I d$.
} 
The jury convicted Weaver of murder and sentenced him to life. Five years later, Weaver filed motion for a new trial. ${ }^{282}$ The trial court ruled Weaver and the Massachusetts Supreme Judicial Court affirmed that Weaver failed to show defense counsel's conduct caused prejudice warranting a new trial. ${ }^{283}$ The U.S. Supreme Court held although the public-trial right is structural, it is subject to exceptions, which suggests that not every public-trial violation results in fundamental unfairness. ${ }^{284}$

\section{Pena-Rodriguez v. Colorado, 137 S. Ct. 855 (U.S. 2017)}

Full Case Citation: Pena-Rodriguez v. Colorado, 137 S. Ct. 855 (U.S. 2017).

2016 CPS Section: V.B.2.c. - Trial Rights / Sixth Amendment Issues / Trial by Jury / Jury Misconduct

\section{Summary:}

This case forced the Court to address a conflict between the no-impeachment rule and a defendant's right to an impartial jury free from racial bias. ${ }^{285}$ A Colorado trial court convicted Peña-Rodriguez of "harassment and unlawful sexual contact." 286 After trial, two jurors told defense counsel — later cemented in an affidavit — that during deliberation another juror repeatedly made statements indicating he thought Peña-Rodriguez was guilty because of his Hispanic heritage. ${ }^{287}$ The juror reportedly restated this belief in several iterations including: "I think he did it because he's Mexican and Mexican men take whatever they want" 288 and "nine times out of ten Mexican men were guilty of being aggressive toward women and young girls." "289

Despite finding bias, the trial court denied Peña-Rodriguez's petition for a new trial. The Colorado Court of Appeals and Supreme Court of Colorado both affirmed on appeal because the juror testimony did not fit within existing exceptions for examining the validity of a verdict listed in Colorado Rule of Evidence 606(b). ${ }^{290}$ The Supreme Court of the United States granted certiorari. $^{291}$

In a 5-3 decision, Justice Kennedy's majority opinion reversed the state courts and created the first constitutional exception to the no-impeachment rule. ${ }^{292}$ The Court held that,

\footnotetext{
282 Id.

283 Id. at $1906-07$.

284 Id. at 1909.

285 Pena-Rodriguez v. Colorado, 137 S. Ct. 855, 868 (U.S. 2017).

286 Id. at 857.

287 Id. at 862.

${ }^{288} I d$. (internal citations omitted).

289 Id. (internal citations omitted).

290 Id. see also CoLO. R. EvID. 606(b); Pena-Rodriguez v. Colorado, 350 P.3d 287 (Colo. 2015); Colorado v. PenaRodriguez, 2012 WL 5457362 (Colo. App. 2012).

291137 S. Ct. at 863.

292 Id.
} 
while safeguards permitting the examination of juror bias before final judgement are sufficient in almost all cases, racial bias influencing the decision of a juror violates the defendant's Sixth Amendment right (applied through the Fourteenth Amendment), and severely obstructs courts from administering just decisions. ${ }^{293}$ However, not all types of racial bias rise to the level necessary to waive the no-impeachment rule. The bias must "cast serious doubt on the fairness and impartiality of the jury's deliberations and resulting verdict" and "show that racial animus was a significant motivating factor in the juror's vote to convict." 294 The Court held the alleged conduct of the juror met that threshold and the impeachment evidence questioning the validity of the verdict should be admitted. ${ }^{295}$

State v. Chapman, 392 P.3d 1285 (Kan. 2017)

Full Case Citation: State v. Chapman, 306 Kan. 266, 392 P.3d 1285 (2017).

2016 CPS Section: V.B.2.c. - Trial Rights / Sixth Amendment Issues / Trial by Jury / Jury Misconduct

\section{Summary:}

Trial court convicted Chapman of first-degree murder. Chapman appealed, arguing the court should have granted his motion for change of venue to prevent a prejudicial jury. ${ }^{296}$ Chapman claimed media coverage about his family, neck tattoo spelling "murder" backwards, and personal background tainted the entire jury pool in his home county. ${ }^{297}$ Chapman asserted this coverage was enough to meet the presumed-prejudice test, but the trial court denied each of his petitions under the Skilling factors test. 298

On appeal, the Supreme Court of Kansas held that while significant media coveragelocally or nationally - could conceivably sway some of the factors in Chapman's favor, media coverage alone does not prove a prima facie instance of presumed prejudice. ${ }^{299}$ In fact, media coverage could be a neutral factor in determining if a change in venue is necessary. ${ }^{300}$ If a story has substantial statewide or national coverage, then the prejudicial jury risk could be just as high in other jurisdictions. ${ }^{301}$ Chapman needed evidence showing the difference between local and regional jury pools that could not be easily reconciled through normal voir dire. ${ }^{302}$

\footnotetext{
293 Id.

$294 I d$. at 869.

295 Id.

296 State v. Chapman, 306 Kan. 266, 266-67, 392 P.3d 1285, 1287 (2017).

297 Id.

298 Id. at 270, 392 P.3d at 1289.

299 Id.at 272-73, 392 P.3d at 1290-91.

300 Id.

301 Id.

302 Id.
} 
Full Case Citation: Lee v. United States, 137 S. Ct. 1958 (2017).

2016 CPS Section: V.B.5.b.ii. - Trial Rights / Sixth Amendment Issues / Right to Counsel/ Personal Choice / Right to Counsel of Choice

\section{Summary:}

In a claim under Strickland v. Washington, counsel is ineffective if the representation falls "below an objective standard of reasonableness" and the defendant was prejudiced by this incompetence (i.e., the error was not harmless). ${ }^{303}$ In Lee v. United States, the issue was whether the Defendant Lee was prejudiced by his counsel's incompetence when his counsel gave him the erroneous advice that pleading guilty to an aggravated felony would not have deportation consequences. ${ }^{304}$

The Defendant had lived in the United States for most of his life, owned businesses in the United States, and had "never returned to South Korea" after moving to the United States. ${ }^{305}$ While running his legal businesses, it appeared the Defendant also had an illegal business selling drugs. ${ }^{306}$ The Government offered the Defendant a plea bargain. ${ }^{307}$ As a lawful permanent resident, defendant worried about being deported and repeatedly asked his attorney whether his immigration status would be affected if he pleaded guilty. ${ }^{308}$ His attorney incorrectly assured him numerous times that pleading guilty would not have deportation consequences. ${ }^{309}$ On the basis of this incorrect advice, the Defendant accepted the deal. ${ }^{310}$

The Defendant argued his counsel was ineffective and the conviction should be vacated because he would not have pleaded guilty if he had known he could be deported. ${ }^{311}$ The district court denied relief. ${ }^{312}$ It reasoned that the Defendant was not prejudiced by the error because the Government had substantial evidence against the Defendant and the Defendant likely would have gone to prison longer and faced deportation anyway if he had gone to trial. ${ }^{313}$ The Sixth Circuit affirmed the district court's ruling. ${ }^{314}$

\footnotetext{
${ }^{303}$ Lee v. United States, 137 S. Ct. 1958, 1964 (2017) (internal quotation marks omitted)(quoting Strickland v. Washington, 466 U.S. 668, 669 (1984)).

304 Id. at 1962.

$305 I d$. at 1963

306 Id.

307 Id.

$308 \mathrm{Id}$.

${ }^{309} I d$.

$310 \mathrm{Id}$.

311 Id.

$312 I d$. at 1964.

$313 \mathrm{Id}$.

${ }^{314}$ Id.
} 
The Supreme Court reversed both the district court and the Sixth Circuit. ${ }^{315}$ It held that the relevant inquiry was not whether the defendant was prejudiced because he would have succeeded at trial. ${ }^{316}$ Rather, the relevant inquiry was whether the defendant was prejudiced because he would have gone to trial if he had been properly advised. ${ }^{317}$ This inquiry is extremely factspecific. ${ }^{318}$

The court rejected the government's argument that a defendant with "no viable defense" per se could not be prejudiced by denial of his right to trial. ${ }^{319}$ While many defendants with no defense and a small chance of winning would likely prefer a plea bargain to the risk of trial and therefore would not be prejudiced by denial of their right to trial, in some cases defendants might prefer to take their chances at trial and therefore would be prejudiced by denial of that right. ${ }^{320}$ The Court found in the unusual circumstances of this case, where deportation was the "determinative issue," there was a reasonable probability that defendant would have chosen a trial that would "[a]lmost certainly" lead to deportation over a plea bargain that would "certainly lead to deportation." 321 Thus, because of counsel's incompetence, defendant suffered prejudice under the Strickland standard. ${ }^{322}$

United States v. Williamson, 859 F.3d 843 (10th Cir. 2017)

Full Case Citation: United States v. Williamson, 859 F.3d 843 (10th Cir. 2017), petition for cert. filed, (U.S. Oct. 18, 2017) (No. 17-6373).

2016 CPS Section: V.B.5.b.ii. - Trial Rights / Sixth Amendment Issues / Right to Counsel/ Personal Choice / Right to Counsel of Choice

\section{Summary:}

Defendant Williamson challenged his sentence on the grounds that the district court abused its discretion in denying his motion for new counsel. ${ }^{323}$ He argued that his attorney had a per se conflict of interest after Defendant filed a criminal complaint against the attorney. ${ }^{324}$ The Tenth Circuit disagreed. ${ }^{325}$ It held that "filing, or threatening to file, a criminal or ethical complaint against an attorney does not per se create a conflict of interest requiring substitution of

\footnotetext{
Id. at 1969.

Id. at 1965.

$I d$. at 1965 .

$318 I d$. at 1966

${ }^{320} I d$. at $1966-67$.

${ }^{321} I d$. at $1968-69$.

322 See id.

${ }^{323}$ United States v. Williamson, 859 F.3d 843, 857 (10th Cir. 2017) petition for cert. filed, (Oct. 18, 2017) (No. 17-
}

319 Id. 6373).

324 Id.

325 Id. 
counsel." 326 It reasoned that while "[a] defendant's grievance against his attorney may establish good cause for substitution of counsel," merely filing a complaint against an attorney is not dispositive of whether the attorney had an actual conflict. ${ }^{327}$

The Tenth Circuit looked to the Second, Fourth, and Eight Circuits for authority on the issue. $^{328}$ These circuit courts hold that the mere fact a defendant filed a disciplinary grievance against an attorney does not necessarily create a conflict of interest such that the attorney's performance would be adversely affected. ${ }^{329}$ The Fourth Circuit noted it would be in the attorney's best interest to do a good job if the attorney knew she might undergo disciplinary proceedings about it later. ${ }^{330}$ Further, the these courts reasoned that adopting an automatic reversal rule could lead to potential problems with defendants trying to "game the system" by filing disciplinary reports in hopes of getting a new attorney on the "eve of trial." 331 For similar reasons, the Tenth Circuit also declined to adopt a per se rule that filing, or threatening to file, a criminal or ethical complaint against an attorney "creates a conflict of interest requiring substitution of counsel." 332 Rather, the Tenth Circuit held, the court must determine whether an attorney is actually "torn between two different interests." 333 Here, statements by the attorney indicated he was concerned about how the record would look on appeal, but not concerned about the allegations defendant had made against him. ${ }^{334}$ This indicated he was not torn between two interests and therefore the district court did not err in denying defendant's motion for new counsel. 335

Khalil-Alsalaami v. State, 399 P.3d 264, (2017)

Full Case Citation: Khalil-Alsalaami v. State, 399 P.3d 264, 54 Kan. App. 2d 235 (2017).

2016 CPS Section: V.B.5.e.i - Trial Rights / Right to Counsel / Effective Assistance of Counsel / Generally

\section{Summary:}

Defendant, Khalil-Alsalaami, challenged his conviction by bringing a claim of ineffective assistance of counsel under K.S.A. $§ 60-1507$ for failing to provide him with an interpreter

\footnotetext{
326 Id.

327 Id.

328 Id. at 858 (citing United States v. Contractor, 926 F.2d 128 (2d Cir. 1991); United States v. Burns, 990 F.2d

1426 (4th Cir. 1993); Winfield v. Roper, 460 F.3d 1026, 1040 (8th Cir. 2006); Smith v. Lockhart, 923 F.2d 1314, 1321 n.11 (8th Cir. 1991)).

329 See id.

330 Id. (quoting United States v. Burns, 990 F.2d 1426 (4th Cir. 1993)).

331 Id. (internal quotations omitted) (quoting United States v. Burns, 990 F.2d 1426 (4th Cir. 1993)).

332 Id. at 857.

333 Id. at 858 ,

334 Id.

335 Id. at 857,859 .
} 
during trial. ${ }^{336}$ Kansas provides a statutory right to an interpreter. ${ }^{337}$ Whether the defendant's English is at such a level that he or she is entitled to an interpreter depends on factors such as "the complexity of the proceedings, the defendant's knowledge of English, and the testimony presented during trial." 338 The defendant here, who worked as a translator with American soldiers in Iraq, primarily spoke Arabic and knew limited English. ${ }^{339}$ While the defendant's lawyer acknowledged he would have difficulty understanding portions of the trial without an interpreter, ${ }^{340}$ the lawyer, fearing the jury would believe the defendant was hiding behind a nonexistent language barrier, advised the defendant against using an interpreter. ${ }^{341}$

The court found the defendant's counsel ineffective. ${ }^{342}$ Turning first to the deficiency question, the court found the attorney failed to test the defendant's English abilities despite knowing that the defendant would be unable to understand certain portions of the trial testimony. ${ }^{343}$ Additionally, the trial involved complex technical information about DNA transference, and the defendant faced a lengthy prison sentence if convicted. ${ }^{344}$ Nor did the attorney explain to the defendant that he had a statutory right to an interpreter. ${ }^{345}$ Finally, the attorney could have addressed the fear of a jury's negative inference through voir dire and a jury instruction. ${ }^{346}$ Noting the defendant was not proficient enough in English to proceed to trial without an interpreter and that a reasonable attorney would not place a trial strategy ahead of the defendant's interest in understanding the trial, the court found the attorney was deficient. ${ }^{347}$

Turning to prejudice, the court relied on State v. Calderon, where the Kansas Supreme Court presumed prejudice when a court instructed an interpreter to not translate closing arguments. ${ }^{348}$ Since Khalil-Alsalaami had been denied an interpreter for the entire trial, the court found the denial to be much worse than in Calderon. ${ }^{349}$ The court held that the defendant was substantially prejudiced by his attorney's errors and was denied a fair trial. ${ }^{350}$

${ }_{36}$ Khalil-Alsalaami v. State, 54 Kan. App. 235, 236-38, 399 P.3d 264, 270-71 (2017).

337 Id. (citing Kan. Stat. Ann. § 75-4351 (1997)).

338 Id. (citing United States v. Carrion, 488 F.2d 12, 14 (1st Cir. 1973)).

339 Id. at 238-40, 399 P.3d at 271-273.

340 Id. at $239-40,399$ P.3d at $272-73$.

341 Id. at 240,399 P.3d at 272.

342 Id. at 244,399 P.3d at 274.

${ }^{343} I d$. at $239-40,399$ P.3d at at $272-73$.

344 Id. at 242,399 P.3d at 273.

345 Id. at 240,399 P.3d at 272.

346 Id.

347 Id. at 244,399 P.3d at 274.

${ }^{348} I d$. at 245, 399 P.3d at 275 (citing 270 Kan. 241, 253-54, 13 P.3d 871, 879 (2000)).

349 Id.

${ }^{350} I d$. at 262,399 P.3d at 284. 
Full Case Citation: State v. Dartez, No. 115,567, 2017 WL 3112819 (Kan. Ct. App. 2017).

2016 CPS Section: V.C.1 - Trial Rights / Evidentiary Issues / Prior Actions by the Defendant

\section{Summary:}

In a domestic dispute, Section 60-455(b) evidence of prior acts of domestic violence or marital dispute may be offered to demonstrate the nature of the relationship of the parties. ${ }^{351}$ The nature of the relationship of the parties is relevant and material if it refutes an argument that the victim was the initial aggressor or is indicative of the motive of the defendant. ${ }^{352}$ In Dartez, the Appellant was convicted of attempted first-degree murder and battery of a woman he had been in a romantic relationship with, however she had expressed her desire to end the relationship. ${ }^{353}$ Appellant challenged the admittance of prior incidents of domestic violence against the victim that occurred a month before the conduct that led to his conviction based on the second and third prongs of admissibility. ${ }^{354}$ Disagreeing, the Court discussed how the nature of the relationship between the Appellant and the victim both refuted the Appellant's argument that the victim was the initial aggressor and that he was unwilling to let the victim end the relationship, which manifested in escalating violence towards the victim. ${ }^{355}$

State v. Perez, 396 P.3d 78 (Kan. 2017)

Full Case Citation: State v. Perez, 396 P.3d 78 (Kan. 2017).

2016 CPS Section: V.C.1 - Trial Rights / Evidentiary Issues / Prior Actions by the Defendant

\section{Summary:}

In Perez, the court clarified that evidence brought in under Section 60-455(d) does not require the trial court to give limiting instructions to the jury, as it would when admitting any other form of prior act evidence, when a defendant is charged with a sex crime because the evidence is admissible for any purpose. ${ }^{356}$ In 2017, the most common claim on appeal regarding the admissibility of prior act evidence was that the trial court improperly failed to give limiting instructions. ${ }^{357}$ The Court's discussion on limiting instructions resolves confusion regarding the obligation of the trial court to give limiting instructions on prior sexual acts where the victim is

\footnotetext{
State v. Dartez, No. 115,567, 2017 WL 3112819, at*3 (Kan. Ct. App. 2017).

$I d$. at $* 4$.

$I d$. at $* 1$.

$354 I d$. at $* 3$.

355 Id. at $* 4$.

356 State v. Perez, 396 P.3d 78, 90 (Kan. 2017) (citing State v. Prine, 303 P.3d 662, 674 (2013)).

357 See, e.g., id.
} 
the same and the conduct at issue is of the same character as the underlying crime. ${ }^{358}$ Because evidence of prior sexual misconduct is admissible for any relevant matter, trial courts do not have to give a limiting instruction when introducing sexual misconduct of the same character as the underlying crime a defendant is charged with. ${ }^{359}$

Further, the Court discussed Section 60-455 evidence admissibility and review, and clarified that trial courts must use a three-part, not a four-part, test to determine the admissibility of prior act evidence. ${ }^{360}$ Trial courts considering the admissibility of prior acts must determine (1) whether the fact to be proven by the evidence is material, (2) whether the evidence is relevant to a disputed fact, and (3) whether the probative value of the evidence outweighs the potential for undue prejudice. ${ }^{361}$ In Perez, the Appellant only took issue with the first prong of the admissibility test and argued that a limiting instruction was required because the evidence admitted of numerous deaths, insurance payouts, and disturbing sexual crimes against minors associated with the Appellant should not have been admitted because, especially the sexual acts, were immaterial and highly prejudicial. ${ }^{362}$ The Court disagreed. ${ }^{363}$ The Appellant was convicted of first-degree premeditated murder, sexual exploitation of a child, eight counts of rape, seven counts of aggravated criminal sodomy, three counts of aggravated assault, and eight counts of making false information. ${ }^{364}$ The prior act evidence was more probative than prejudicial and was of the same character as the charges against the Appellant. ${ }^{365}$

State v. Williams, 306 Kan. 175; 392 P.3d 1267 (2017)

Full Case Citation: State v. Williams, 306 Kan. 175; 392 P.3d 1267 (2017).

2016 CPS Section: V.C.5. - Trial Rights / Evidentiary Issues / Cross-Examination

\section{Summary:}

After a jury convicted Defendant Williams of distribution of methamphetamine, Williams appealed the district court's admittance of an audio recording of statements from a non-testifying informant. ${ }^{366}$ Williams argued that admitting the statements violated his Sixth Amendment right of confrontation because the informants' statements were testimonial in nature. ${ }^{367}$ The informant met with KBI Agent Lind and arranged for Lind to purchase meth from Williams. ${ }^{368}$ Lind wore a

\footnotetext{
58 See id. at 90-91.

359 Id.

360 See id. at 89 (citing State v. Richard, 333 P.3d 179, 185 (2014)).

361 Id.

362 Id.

363 Id. at 90.

$364 I d$. at 81 .

365 Id. at 90.

366 State v. Williams, 306 Kan. 175, 176, 392 P.3d 1267, 1269 (Kan. 2017).

367 Id. at 177,392 P.3d at 1269.

368 Id. at 176, 392 P.3d at 1269-70.
} 
body wire during the purchase and recorded audio of the entire transaction. ${ }^{369}$ Portions of the audio contained statements of the informant, who, although subpoenaed to testify, did not appear at trial. ${ }^{370}$ The district court admitted the entire audio recording in as evidence, finding that the informant's statements were not testimonial in nature and therefore did not violate Williams' right of confrontation. ${ }^{371}$ A panel of the Kansas Court of Appeals affirmed the district court's finding, relying on a four-factor test from State v. Brown to determine whether the statements in the audio recordings were testimonial. ${ }^{372}$

The Kansas Supreme Court rejected the lower court's strict application of the Brown factors to determine whether a statement qualifies as testimonial. The court noted that the factors in Brown "were based on precedent from the United States Supreme Court and [the Kansas Supreme Court] then available." 373 The Brown test was, in other words, "a creature of its time."'374 And because the United States Supreme Court decided several Confrontation Clause cases defining the scope of testimonial statements since Brown, the Kansas Supreme Court determined that an analysis of those decisions was necessary to determine whether the admission of the informant's statements violated Williams' right to confrontation. ${ }^{375}$

The court then reviewed Supreme Court Confrontation Clause cases to determine the validity of admitting the informant's statements. ${ }^{376}$ After reviewing those cases, the Kansas Supreme Court concluded that Brown's factors were no longer the "exclusive or all-encompassing template for determining whether a statement made by an absent declarant qualifies as testimonial." "377 Most importantly for Williams, the lower court's application of Brown's factors relied heavily "on the fact that the informant's statements were not made during a police interrogation." 378 However, the Supreme Court's post-Brown cases clarified that "the class of

\footnotetext{
369 Id. at 177,392 P.3d at 1270.

$370 I d$.

371 Id.
}

372 Id. at 178-79, 392 P.3d at 1271 (citing State v. Brown, 285 Kan. 261, 291, 173 P.3d 612, 634 (Kan. 2007)). The Brown factors are: "(1) Would an objective witness reasonably believe such statement would later be available for use in the prosecution of a crime; (2) Was the statement made to a law enforcement officer or to another government official; (3) Was proof of facts potentially relevant to a later prosecution the primary purpose of the interview when viewed from an objective totality of the circumstances ... and (4) Was the level of formality of the statement sufficient to make it inherently testimonial .... Brown, $285 \mathrm{Kan}$. at 291, 173 P.3d at 634.

373 Williams, 306 Kan. at 182, 392 P.3d at 1272 (emphasis added). The court cited four cases upon which the Brown test aggregated its factors: State v. Miller, 284 Kan. 682, 163 P.3d 267 (2007), and State v. Henderson, 284 Kan. 267, 160 P.3d 776 (2007); Davis v. Washington, 547 U.S. 813 (2006); Crawford v. Washington, 541 U.S. 36 (2004).

374 Williams, 306 Kan. at 197, 392 P.3d at 1281.

375 Id. at 182,392 P.3d at 1273 (stating that although the "Supreme Court has not yet directly addressed statements made by informants ... we review its decisions in this area for the guidance they can provide on the federal constitutional question before us today.").

${ }_{376}$ Id. at 182-194, 392 P.3d at 1273-1280. See Ohio v. Clark, 135 S. Ct. 2173 (2015); Bullcoming v. New Mexico, 564 U.S. 647 (2011), Michigan v. Bryant, 562 U.S. 344 (2011); Melendez-Diaz v. Massachusetts, 557 U.S. 305 (2009); Davis v. Washington, 547 U.S. 813 (2006); Hammon v. Indiana 546 U.S. 976 (2006); Crawford v. Washington, 541 U.S. 36 (2004).

377 Williams, 306 Kan. at 197, 392 P.3d at 1281.

${ }^{378} I d$. at 198,392 P.3d at 1281. 
testimonial statements . . is broader than formal statements made to police during an interrogation to solve a crime."379

Accordingly the court adjusted its analysis to mirror United States Supreme Court .... precedent in which courts conduct an objective analysis of the circumstances surrounding the statements. ${ }^{380}$ The court considered the fact that the statements "were made during a controlled drug buy set up for the express purpose of creating evidence for use at a future prosecution." 381 The court also found significant that one of the statements on the recording was made to Lind, a law enforcement officer. ${ }^{382}$ Additionally, the primary purpose of the drug buy was to obtain evidence to convict Williams. ${ }^{383}$ For these reasons, "an objective witness in the informant's position would 'reasonably believe' her statements 'would later be available for use in the prosecution of a crime," those statements were "inherently testimonial," and therefore the statements were sufficient to qualify as testimonial. ${ }^{384}$ Because the informant's statements were testimonial, the district court's decision to admit the statements violated Williams' Sixth Amendment right of confrontation. ${ }^{385}$ Although the court agreed that admitting the informant's statements violated Williams' confrontation right, the court nevertheless affirmed Williams' conviction because admitting the statements was harmless error. ${ }^{386}$

\section{Sentencing}

KAN. STAT. ANN. § 21-6620 (West 2017);

KAN. STAT. ANN. § 21-6627 (West 2017).

Full Case Citation: Kan. StAT. AnN. § 21-6620 (West 2017); KAn. StAT. AnN. § 21-6627 (West 2017).

2016 CPS Section: VI.B.1.b.- Sentencing / Kansas Sentencing / Sentencing Determination / Hard 40/50 Sentences

\section{Summary:}

K.S.A. $\S \S 21-6620$ and K.S.A. $\S 21-6627$ both explain the application of mandatory minimum sentences for certain crimes. ${ }^{387}$ In 2017, the Kansas Legislature amended both K.S.A. $\S \S 21-6620$ and 21-6627, making minor changes to the wording in each. ${ }^{388}$ In addition to these

\footnotetext{
379 Id. at 197, 392 P.3d at 1281; See also id. at 198, 392 P.3d at 1282 ("[T]he Crawford Court never intended to imply that statements made by an informant are per se beyond the scope of the Confrontation Clause.").

380 Id. at 200, 392 P.3d at 1283.

381 Id. at 200-01, 392 P.3d at 1283.

$382 I d$. at 202,392 P.3d at 1284.

383 Id.

384 Id. (quoting State v. Brown, 285 Kan. 261, 291, 173 P.3d 612, 634 (Kan. 2007)).

385 Id. at 202, 392 P.3d at 1284.

386 Id. At trial, the prosecution delivered extensive overwhelming evidence against Williams which was sufficient to support the jury's conviction independent of the inclusion of the informant's statements. Id. at 203, 392 P.3d at 1284.

387 Kan. Stat. AnN. § 21-6620 (West 2017); Kan. Stat. AnN. § 21-6627 (West 2017).

388 H.B. 2092, 2017 Leg. Sess. (Kan. 2017).
} 
minor changes, the legislature added two clarifying sentences to K.S.A. $§ 21-6620$ subsections (a)(2)(B), (b)(2), (c)(1)(B) and (c)(2)(B). ${ }^{389}$ These sections address when the mandatory minimum of 25 years does not apply. ${ }^{390}$ Prior to the 2017 amendments, if the defendant "would be subject to presumptive imprisonment" under the sentencing grid and the sentencing range exceeded 300 months, the statute called for the defendant to be sentenced according to the mandatory minimum under the sentencing grid. ${ }^{391}$ After the amendment, when a defendant "would be subject to presumptive imprisonment pursuant to the sentencing guidelines grid for nondrug crimes and the sentencing range would exceed 300 months if the sentence established for a severity level 1 crime was imposed," the defendant receive a mandatory minimum sentence "equal to the sentence established for a severity level 1 crime" under the sentencing grid. 392 Additionally, the amended sections state that no parole is available to the defendant until the defendant has served the mandatory minimum. ${ }^{393}$ Further, the amendments prohibit the application of good time credits to reduce the sentence." 394

State v. Allen, 407 P.3d 661 (Kan. Ct. App. 2017)

Full Case Citation: State v. Allen, 55 Kan. App. 2d 87, 407 P.3d 661 (2017).

2016 CPS Section: VI.B.1.d.- Sentencing / Kansas Sentencing / Sentencing Determination / Consecutive \& Concurrent Sentences

\section{Summary:}

Marcus William Allen was on probation in two separate cases when he violated the terms of both probation periods. ${ }^{395}$ In both cases Allen stipulated that he had violated his probation. ${ }^{396}$ In each case the judge ordered 60-day probation periods. ${ }^{397}$ At the second hearing, the judge ordered the two 60-day probation sanctions to run consecutively, for a total of 120 days probation. ${ }^{398}$ Allen objected, relying on K.S.A. 2016 Supp. 22-3716(c)(10) which provides that "[i]f an offender is serving multiple probation terms concurrently, any violation sanctions imposed ... pursuant to subsection (c)(11), shall be imposed concurrently."399 The district court overruled his objection. ${ }^{400}$

\footnotetext{
389 Id.

$390 \mathrm{Id}$.

391 Id.

392 Id.

393 Id.

394 Id.

395 State v. Allen, 55 Kan. App. 2d 87, 87-88, 407 P.3d 661, 66263 (2017).

${ }^{396} I d$. at 88,407 P.3d at 663 .

397 Id.

398 Id.

399 Id. at 89, 407 P.3d at 663.

${ }^{400} \mathrm{Id}$.
} 
The Court of Appeals reversed the district court and held that the statute does prohibit ordering probations to run consecutively. ${ }^{401}$ Although the State argued that the statute's probation violations should only apply to proceedings in a single district court, the Court of Appeals reasoned that "there are two triggers to the application of [the statute's] rule. First, the offender must be 'serving multiple probation terms concurrently.' Second, violation sanctions must be imposed under one of the listed subsections. If those conditions are met, then any sanction "shall be imposed concurrently." 402 Because Allen was serving multiple probation terms concurrently and the sanctions were imposed under one of the listed subsections, the district court was required to order Allen's probation to run concurrently. ${ }^{403}$

401 Id. at 91, 407 P.3d at 664.

$402 I d$. at 89,407 P.3d at 663 .

403 Id. at 91, 407 P.3d at 664 . 